\title{
Ozone-Depleting-Substance Control and Phase-Out Plan
}

Coordinated by

Office of Environmental Assurance, Permits and Policy U.S. Department of Energy, Richland Operations Office

Prepared by

J. M. Nickels

M. J. Brown

United States

P.O. Box 550

Richland, Washington 99352

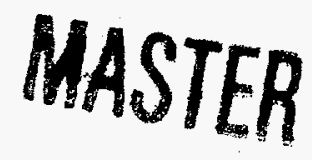




\section{DISCLAIMER}

This report was prepared as an account of work sponsored by an agency of the United States Government. Neither the United States Government nor any agency thereof, nor any of their employees, make any warranty, express or implied, or assumes any legal liability or responsibility for the accuracy, completeness, or usefulness of any information, apparatus, product, or process disclosed, or represents that its use would not infringe privately owned rights. Reference herein to any specific commercial product, process, or service by trade name, trademark, manufacturer, or otherwise does not necessarily constitute or imply its endorsement, recommendation, or favoring by the United States Government or any agency thereof. The views and opinions of authors expressed herein do not necessarily state or reflect those of the United States Government or any agency thereof. 


\section{DISCLAIMER}

Portions of this document may be illegible in electronic image products. Images are produced from the best available original document. 
DOE/RL-94-86

\section{CONTENTS}

1.0 EXECUTIVE SUMMARY . . . . . . . . . . . . . . . . . . 1

2.0 INTRODUCTION . . . . . . . . . . . . . . . . . . . 1

3.0 TECHNICAL ACTIVITIES . . . . . . . . . . . . . . . . . . . 3

3.1 OPERATIONS, MAINTENANCE, AND CONTROL OF

REFRIGERANT SYSTEMS CONTAINING ODSS ............. 3

3.1.1 Requirement ................. 3

3.1.2 Implementation Process . . . . . . . . . . . . 3

3.1.3 Labeling Requirements . . . . . . . . . . . . . . 5

3.1:4 Recordkeeping Requirements . . . . . . . . . . . . 5

3.2 PROCUREMENT OF CONTRACTED SERVICES . . . . . . . . . . . 6

3.2.1 Background . . . . . . . . . . . . . . . 6

3.2 .2 Contracts ................. . . 6

3.3 ENERGY MANAGEMENT ...................... 6

3.3.1 Requirement . . . . . . . . . . . . . . . . . 7

3.3.2 Implementation Process ............... 7

3.4 TRAINING AND CERTIFICATION ..................... 8

3.4.1 Requirement ................. 8

3.4.2 Implementation Process . . . . . . . . . . 8

3.5 CONTAINER, PRODUCT, AND EQUIPMENT LABELING AND MARKING . . . 10

3.5.1 Requirement .................. 10

3.5.2 Implementation Process . . . . . . . . . . 11

3.6 SIGNIFICANT NEW ALTERNATIVES POLICY PROGRAM . . . . . . . . 11

3.6.1 Criteria for Review . . . . . . . . . . ..... 11

3.7 PROCUREMENT 12

3.8 PRODUCTS AND SOLVENT USES . . . . . . . . . . . . . . . . . 13

3.9 FIRE SUPPRESSION SYSTEMS .................. 13

3.9.1 Requirement .................... 13

3.9.2 Implementation Process . . . . . . . . . . . . 13

3.10 MOTOR-VEHICLE AIR CONDITIONING SERVICE AND MAINTENANCE $\ldots . \quad$. 14

3.10.1 Requirement . . . . . . . . . . . . . . . . 14

3.10.2 Implementation Process ............. 15

4.0 INDIVIDUAL CONTRACTOR PROGRAMS . . . . . . . . . . . . . 17

4.1 WHC PROGRAM .................... 17

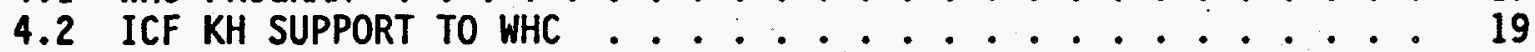

4.3 PACIFIC NORTHWEST LABORATORY PROGRAM . . . . . . . . . . . 19

4.4 BECHTEL HANFORD, INC. PROGRAM ................. 21

4.5 HANFORD ENVIRONMENTAL HEALTH FOUNDATION PROGRAM . . . . . . . 21

5.0 COMPLIANCE VERIFICATION . . . . . . . . . . . . . 22

6.0 GLOSSARY . . . . . . . . . . . . . . . . . . . 22

7.0 REFERENCES . . . . . . . . . . . . . . . . . . 25 
DOE/RL-94-86

CONTENTS (cont)

APPENDIXES

I MAINTENANCE FORMS .................... . . I-1

II ACCEPTABLE ODSS .................... . . . . II-1

III HALON 1301 PHASE-OUT PROGRAM ................ III-1

IV CERTIFIED RECYCLING AND RECLAMATION EQUIPMENT . . . . . . . IV-1

\section{LIST OF FIGURES}

1 Motor-Vehicle Refrigerant Service Log . . . . . . . . . . . . 18

\section{LIST OF TABLES}

1 Facilities Removed From Service . . . . . . . . . . . . . . . 14

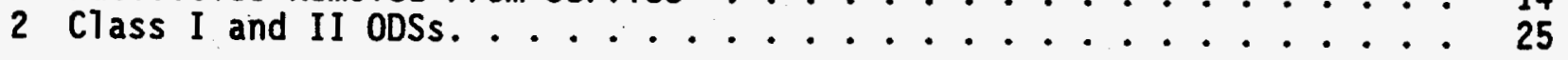


DOE/RL-94-86

TERMS

ARI

BHI

CAA

CFC

CFR

D\&D

DOE

E\&O

Ecology

EO

EPA

ERC

FFTF

FMEF

GSA

HBFC

HCFC

HEHF

HGET

HVAC

ICF KH

IHEM

MOA

MVAC

ODS

PNL

RCRA

RCW

RL

RSES

SNAP

TSD

WHC

Air Conditioning and Refrigeration Institute Bechtel Hanford, Inc.

Clean Air Act of 1955

chlorofluorocarbon

Code of Federal Regulations

decontamination and decommissioning

U.S. Department of Energy

Engineering and Operations

Washington State Department of Ecology

executive order

U.S. Environmental Protection Agency

Environmental Restoration Contract

Fast Flux Test Facility

Fuels Manufacturing Examination Facility

General Services Administration

hydrobromofluorocarbon

hydrochlorofluorocarbon

Hanford Environmental Health Foundation

Hanford General Employee Training

heating, ventilation, and air conditioning

ICF Kaiser Hanford

in-house energy management

memorandum of agreement

motor-vehicle air conditioner

ozone-depleting substances

Pacific Northwest Laboratory

Resource Conservation and Recovery Act of 1976

Revised Code of Washington

U.S. Department of Energy, Richland Operations Office

Refrigeration Service Engineering Society

significant-new-alternatives policy

treatment, storage, and disposal

Westinghouse Hanford Company 
DOE/RL-94-86

This page intentionally left blank. 


\section{OZONE-DEPLETING-SUBSTANCE CONTROL AND PHASE-OUT PLAN}

\subsection{EXECUTIVE SUMMARY}

Title VI of the Federal Clean Air Act Amendments of 1990 requires regulation of the use and disposal of ozone-depleting substances (ODSs) (e.g., Halon , Freon ${ }^{2}$ ). Several important federal regulations have been promulgated that affect the use of such substances at the Hanford Site. On April 23, 1993, Executive Order (E0) 12843, Procurement Requirements and Policies for Federal Agencies for Ozone-Depleting Substances (EPA 1993) was issued for Federal facilities to conform to the new U.S. Environmental Protection Agency (EPA) regulations implementing the Clean Air Act of 1963 (CAA), Section 613, as amended.

To implement the requirements of Title VI, the U.S. Department of Energy, Richland Operations office (RL), issued a directive to the Hanford Site contractors on May 25, 1994 (Wisness 1994). The directive assigns Westinghouse Hanford Company (WHC) the lead in coordinating the development of a sitewide comprehensive implementation plan to be drafted by July 29, 1994 and completed by September 30, 1994. The implementation plan will address several areas where immediate compliance action is required. It will identify al1 current uses of ODSs and inventories, document the remaining useful life of equipment that contains ODS chemicals, provide a phase-out schedule, and provide a strategy that will be implemented consistently by all the Hanford site contractors. This plan also addresses the critical and required elements of Federal regulations, the EO, and U.S. Department of Energy (DOE) guidance. This plan is intended to estabiish a sitewide management system to address the clean air requirements.

Washington State is proposing regulations that are more stringent in some areas than the Federal regulations. As a living document, this plan will address the State regulations after they are promulgated.

The Washington Public Power Supply System and U.S. Ecology are not covered by this plan because their sites are not under the control of RL.

\subsection{INTRODUCTION}

This plan will provide the clean air requirements and a general overview of how the Hanford Site contractors will implement a program to achieve compliance with them. This plan is being prepared to satisfy the requirements of preparing a project management plan contained in DOE Order 4700.1 (DOE 1987).

In September 1987 the United States and 22 other countries signed the Montreal Protocol on Substances that Deplete the Ozone Layer to 1 imit

\footnotetext{
${ }^{1} \mathrm{Ha}$ on is a trademark of Allied Chemical Corporation.

${ }^{2}$ Freon is a trademark of E. I. duPont de Nemours \& Co.
} 
worldwide production of chlorofluorocarbons (CFCs) and Halons. Three years later, the parties to the Montreal Protocol agreed to institute a complete phase-out of CFCs, Halons, and carbon tetrachloride by the year 2000 and a complete phase-out of methyl chloroform by the year 2005. The parties also passed a non-binding resolution at the June 1990 meeting calling for a total phase-out of hydrochlorofluorocarbons (HCFCs) by the year 2040.

Title VI of the Federal CAA Amendments of 1990 became the statutory vehicie for implementing the provisions of the Montreal Protocol in the United States. As enacted, Title VI modified the production phase-out schedules of the Montreal Protocol by advancing the phase-out deadline for methyl chloroform to the year 2002 and mandating the phase-out of HCFCs by the year 2030. Title VI also provided for the further acceleration of such schedules if necessary to protect human health and the environment, if practicable in light of the development of acceptable substitutes, or if required to reflect further changes in the Montreal Protocol.

In late 1992 the parties to the Montreal Protocol voted to require the phase-out of HCFCs and to accelerate the existing phase-out schedules for Class I substances (see Glossary, Chapter 6, for definition). The new. schedules called for halon production to be completely phased out by 1994; CFC, carbon tetrachloride, and methyl chloroform production to be phased. out by 1996; and HCFC production to be phased out by 2030 . The 1992 Amendments to the Montreal Protocol al so added methyl bromide and hydrobromofluorocarbons (HBFCS) to the list of Class I substances. The parties voted to freeze methyl bromide production at 1991 levels by 1995 and to completely phase out HBFC production by 1996 . Title VI establishes use restrictions, recycling and recovery requirements, and labeling requirements. It also establishes requirements for servicing of motor-vehicle air conditioners (MVAC), a safealternatives policy, and a ban on nonessential products. Rules addressing these requirements have been promulgated at Title 40 , Code of Federal

Regulations (CFR), Part 82, "Protection of Stratospheric Ozone." A summary of the final regulations are as follows:

- Accelerated phase-out and MVAC rule (July 1992)

- Ban on nonessential use (February 1993)

- Labeling rule (March 1993)

- Recycle and recovery rule (May 1993)

- Procurement rule (October 1993)

- Significant new alternatives policy (SNAP) rule (March 1994).

EPA has completed all promulgating actions under Title VI of the CAA.

To effectively implement and conform to many of these requirements at Federal facilities, the President issued EO 12843 on April 23, 1993. The order addressed the need to identify safe alternatives, conform procurement policies to the Title VI requirements, implement the labeling requirements, and evaluate present and future uses of recycling and phase-out of ODS chemicals. DOE drafted a refrigerant management plan in November 1993 to implement the EO. The refrigerant management plan was completed and issued as Recommended Approaches to Management of Refrigerants at DOE Facilities (DOE 1994). 


\subsection{TECHNICAL ACTIVITIES}

\subsection{OPERATIONS, MAINTENANCE, AND CONTROL OF REFRIGERANT SYSTEMS CONTAINING ODSS}

This section provides guidance to implement the requirements of the refrigerant management plan for DOE facilities, which was drafted by DOE Headquarters in November of 1993. The goal of that plan was to phase out the use of ODSs by systematically implementing environmentally safe alternative substances and processes.

This section addresses management of all refrigerants using ODSs on the Hanford Site, except those systems present in motor vehicles. ODSs present within motor vehicles will be addressed separately within Section 3.9 of this plan.

\subsubsection{Requirement}

As a user of ODSs, RL and its contractors at the Hanford Site are not directly involved in meeting the production phase-out schedule requirements of the CAA. However, both the Federal procurement requirements (48 CFR 2) and EO 12843 establish a policy for Hanford and other DOE sites to maximize their use of safe alternatives and minimize, where economically practicable, the procurement of Class I ODSs. In addition, the diminishing availability of Class I substances as production is phased out supports the need to develop long-range plans for managing CFC refrigerant supplies.

\subsubsection{Implementation Process}

The Hanford Site contractors will pursue a systematic approach to identify and evaluate refrigerant equipment in Hanford Site facilities. That approach will consist of the following activities:

- Conduct a systematic inventory to identify all pieces of equipment containing more than $2 \mathrm{lb}$ of ODSs used as refrigerant. The equipment inventory will provide information needed to determine if equipment is to be retained, retrofitted, or replaced. Each piece of equipment containing more than 2 1b of ODS refrigerant will be listed separately. Equipment containing 2 lb or less of like refrigerant may be grouped within a building or facility (e.g., refrigerators, drinking fountains). The database structure and inventory form are shown in Appendix I.

Each $\mathrm{RL}$ facility will review refrigeration systems within their control. These reviews will consider future requirements, energy efficiency improvements, and present condition and age. This information will be used to determine whether equipment will be retrofitted, replaced, or abandoned at the end of useful 1 ife. Those systems meeting the requirements for replacement will be evaluated in terms of risk of failure, then ranked by priority for replacement. The key requirement for replacement involves the equipment reaching the end of its useful life. Priorities will be 
established for each facility across the Hanford Site. Information collected during the inventory will be accessible to facility management and maintenance service organizations to expedite transfer of spare parts and refrigerant among the facilities.

Ready stocks of recycled refrigerant will be maintained in a central location for reuse. New and reclaimed refrigerant also will be maintained at a central location (to be determined). The data collected on available refrigerants will be used to identify potential sources of available refrigerant. This central collection and dispersal effort will avoid costly purchases of diminishing refrigerant supplies and reduce waste streams from equipment removed from service.

- Establish a database to track all equipment identified during the systematic inventory. Included in the database will be the ability to track leakage from systems for compliance with Subpart F of $\mathbf{4 0}$ CFR 82.

- Establish a proactive leak-determination practice. The Hanford Site contractors will input data on refrigeration systems to a central database. The database will generate periodic reports of leaks from equipment containing more than $2 \mathrm{lb}$ of refrigerant to ensure that repairs are performed in compliance with Subpart $F$ and that releases are included in periodic reports required by the CAA Air Operating Permit requirements. Indications of service and selected service data will also be retained. Service records will be maintained in the facility work control center. The maintenance and service records will be used to determine the leak rates on an inventory basis.

The following leak-rate calculation shall be used to determine leak rates from the maintenance and service records:

$$
\text { Leak Rate }=\frac{\text { (refrigerant added during last charge })(365 \mathrm{~d})(100 \%)}{\text { (total system charge) (days between last two charges) }}
$$

The result is then compared to the 15-percent annualized leak rate allowed for comfort-cooling appliances. If the result is greater than 15 percent, the leaks must be repaired within 30 days of the discovery of the excessive leak rate.

- Establish a program to recover and recycle all refrigerants by the use of EPA-approved equipment operated by EPA-certified technicians. To the maximum extent possible, refrigerants containing ODSs will be recycled and reused. Refrigerants may be reused within the unit being serviced or moved to a central storage location for reuse in other systems. When recycling is not possible (e.g., damage to the refrigerant from flame), the refrigerant will be sent to EPAapproved reclamation facilities. Following reclamation, the refrigerant will be returned to the Hanford Site or provided to other Federal sites. 
New supplies of available refrigerants containing ODSs will be procured if necessary only after existing available supplies have been exhausted. Modification to refrigeration systems will be made to allow for replacement of refrigerants only after all other options have been exhausted. Surplus stocks of ODSs may be sold on the open market to offset the cost of developing and implementing the program.

- Establish and implement a method to evaluate the retrofit, replacement, and abandonment of existing large refrigerant systems with energy-efficient, cost-effective systems. All large refrigerant systems (see Glossary, Chapter 6, for definitions) will be evaluated using established life-cycle cost-analys is techniques and in-house energy-management (IHEM) methods. Consideration will be given to the remaining useful life of the equipment, required process life of the facility, facility process cooling requirements, reasonable payback period, and retrofit options. Each refrigerant system will be assigned a replacement priority. The priority will be reevaluated after major facility process or mission changes and before any major repair projects are initiated. The evaluation process is described in more detail in the Energy Management section of this plan.

\subsubsection{Labeling Requirements}

Establish a program to only label refrigerant systems and containers that are shipped off site (introduced into interstate commerce) to indicate the presence of ODSs. The Hanford Site contractors will comply with the container labeling requirements set forth in 40 CFR 82, Subpart $E$.

\subsubsection{Recordkeeping Requirements}

The EPA has established the following recordkeeping requirements at Subpart F, 40 CFR 82:

- Recycle/recovery equipment owners. Facilities maintaining; servicing, or repairing appliances (except for MVACs), and disposing of appliances (except small appliances, MVACs, and MVAC-like equipment) must certify that they have acquired and are properly using certified recovery or recycling equipment.

- Owners of air-conditioning and refrigeration equipment. Owners/operators are to maintain appliance servicing records. Data include records of the service calls, dates of such service calls, and amounts of refrigerant added. Records must also include refrigerants purchased. Service records and work packages will be maintained by the facilities' work-control systems.

- Disposers. Facilities disposing of small appliances, MVACs, and MVAC-like appliances must maintain copies of signed statements. Such statements shall verify that the refrigerant has been evacuated from the appliance. Records of disposed appliances shall be kept at the facilities that are disposing of the appliances. 
A11 records that must be maintained to comply with 40 CFR 82 , Subpart $F$ must be kept for at least 3 years unless otherwise indicated by the EPA.

\subsection{PROCUREMENT OF CONTRACTED SERVICES}

\subsubsection{Background}

This section describes Hanford Site heating, ventilation, and air conditioning (HVAC) service contracts currently in place. Provisions of these contracts are in accordance with the Federal acquisition regulations and the DOE acquisition regulations. This section also describes the contracted services performed by offsite vendors for RL. Existing contracts will be adjusted to conform to DOE policy to use non-ODS-containing products where economically and technically feasible.

\subsubsection{Contracts}

Maintenance and Service Contract for 400 Area Facilities. WHC manages a maintenance and service contract on the 400-ton chillers located at the Fast Flux Test Facility (FFTF) and the Fuels Manufacturing Examination Facility (FMEF) at the 400 Area. The contract is maintained and administered annually through WHC Procurement. Work is controlled through work packages prepared and maintained by WHC FFTF/FMEF Maintenance. Minor work on the chillers is accomplished by properly trained and certified plant employees.

General Maintenance and Service Contract. The contract is considered an " $8 A$ " (small business) contract awarded sole source to an offsite contractor. The contractor is required to comply with stated regulations included within the text of the contract. RL assigns monitoring of the technical provisions of the contract to specific WHC/Boeing Computer Services, Richland and ICF Kaiser Hanford (ICF KH) personnel.

ICF KH manages maintenance and services that provide for inspection, preventive maintenance, and overhaul services, which includes dismantling, examination, replacement of existing installed HVAC, chemical, and ammonia systems in 23 DOE contractor-maintained Site buildings, the Federal Building, and 2 contractor-leased facilities for WHC. Such services also may be provided to additional facilities, subject to the approval of RL.

All work performed on existing HVAC systems is expressly subject to the provisions of the Davis-Bacon Act, as amended, and the applicable provisions of the WHC contract with RL.

\subsection{ENERGY MANAGEMENT}

This section describes how energy management practices will be combined with other engineering practices to ensure that equipment containing ODSs will be evaluated for retrofit or replacement. It al so describes how 1 ife-cycle cost analyses and use of energy management practices will be combined to provide opportunities to retrofit or replace equipment containing ODSs. 


\subsubsection{Requirement}

In DOE Order 6430.1A (DOE 1989), DOE reduced its immediate dependence on CFCs as refrigerants. DOE established criteria requiring reduction of dependence on CFCs in new and replacement refrigerant systems by limiting refrigerant use to HCFC 22 where feasible. These criteria apply to projects in planning, programming, and Title 1 design as of the date of order implementation and to projects in Title II design and under construction where technically and economically feasible.

\subsubsection{Implementation Process}

At the Hanford Site, refrigerants CFC 11 and 12 are used extensively in the refrigerant systems in nuclear reactors, chemical processing plants, and laboratory facilities. With the change in mission from defense production to environmental restoration many of these reactors, plants, and laboratories are being placed in standby or are being transitioned to a surveillance and maintenance phase for final decontamination and decommissioning. Taking these facilities out of production significantly reduced their heat removal requirements, making many large cooling systems using Class I ODSs too large for their current and future uses. However, immediate replacement of these systems with new systems using a SNAP refrigerant is not economically feasible in light of competing funding priorities. Therefore, an alternative systematic engineering approach must be used to evaluate refrigeration systems to ensure that costs, operating efficiency, worker safety, and cessation of use of regulated refrigerants are considered.

Evaluation of Existing Systems. Existing systems shall be evaluated using 1 ife-cycle cost analysis methods. Life-cycle cost analys is requires that new equipment procurement costs, installation, efficient operation, and maintenance during operating life, as well as equipment and refrigerant disposal be considered. Existing systems will be evaluated as part of the oDS implementation effort. Priorities will be based on refrigerant type, leak rates, maintenance and service frequencies, facility or process missions, and availability of suitable SNAP refrigerants.

Future Activities. Under this plan, the Hanford Site contractors will complete their inventories of a17 equipment and systems using ODSs by the end of fiscal year 1995. From the completed inventory, the contractors will identify and evaluate refrigerant systems that use ODSs on schedule for production phase-out and that require retrofit or replacement based on leak rates, required future uses, and IHEM and DOE Order 6430.1A criteria. Energy Management will review all retrofit and replacement projects identified through the ODS implementation effort for potential IHEM funding and to ensure that energy conservation measures are considered. A1I IHEM proposed projects will be developed and evaluated using IHEM requirements provided by Energy Management. All projects will be evaluated for the effects of 1 ife-cycle costs. The contractors will al so update construction and design specifications for the Site to address the use of alternative refrigerants and energy-efficiency measures. 


\subsection{TRAINING AND CERTIFICATION}

At the Hanford Site, various technicians, crafts workers, and service engineers perform genera7 maintenance, service, and repair on refrigerant systems that contain regulated $\mathrm{Cl}$ ass I or II ODSs. This section describes the training and certification requirements for the individual Hanford Site contractors as required by Title VI of the CAA 1990 Amendments.

An effective educational program aimed at preparing technicians for the certification test has been developed that will increase compliance with the CAA requirements, leading to better environmental protection.

\subsubsection{Requirement}

Subpart F of 40 CFR 82, "Refrigerant Recycling," requires persons servicing air-conditioning and refrigeration equipment to observe certain service practices that reduce refrigerant emissions, as well as complete a technician training and certification program. At the Hanford Site, the regulations apply to technicians working on air-conditioning systems and the equipment that they use.

The Subpart $F$ regulations establish requirements and provisions for training and certification. The regulations require varying levels of certification for those persons that could reasonably be expected to release ODSs into the atmosphere during handling, service, maintenance, or repair. The EPA strongly encourages appropriate training of all individuals whose job responsibilities have any impact on the release of ODSs to the atmosphere. All technicians must pass an examination administered by an EPA-approved testing organization. Technicians must be certified by November 14, 1994.

\subsubsection{Implementation Process}

Hanford Site Training and Certification Practices. Two types of training are currently conducted at the Hanford Site: general employee awareness training and technician certification by an EPA-approved testing organization. Because many Site employees frequently are exposed to work situations where one may inadvertently or unintentionally release ODSs to the atmosphere, a general employee awareness training will be included in the Hanford General Employee Training (HGET) program beginning in April 1995.

An EPA-approved certification program, operated by Martin Marietta Energy Systems at Oak Ridge National Laboratory's K-25 facility in Oak Ridge, Tennessee, has been introduced to the Hanford Site contractors. This program is being adopted to comply with the technician certification requirements. Because ICF KH will be managing the central sitewide ODS inventory, ICF KH also will manage the technician certification program that will be available to the Hanford Site contractors.

Approved certifying programs will receive a letter of approval from the EPA. The EPA is requiring that each testing center display a copy of that approval. A copy of the Oak Ridge National Laboratory certification program approval will be retained at the Hanford Site (ICF KH training organization). 
Training Program. Each contractor shall ensure that all personnel responsible for servicing, maintaining, repairing, or disposing of equipment containing ODSs and equipment used to capture or recycle ODSs, receive appropriate training and EPA-approved certification. At a minimum, the program shall:

- Include personnel responsible for maintaining and servicing MVAC and industrial and commercial refrigeration and cooling equipment, i.e., HVAC, chillers, coolers, and freezers

- Meet or exceed the applicable regulatory requirements of 40 CFR 82 for technicians.

The training organization for each contractor shall ensure that training is available to the appropriate employees.

Types of Certification. The EPA has created four separate technician certification categories that cover the various types of air conditioning and refrigeration equipment being serviced and maintained. The types of equipment covered by certification are as follows:

- Small appliances (e.g. household appliances, water coolers, etc.) (Type I certification)

- High-pressure equipment with a charge of less than 50 1b (e.g. unitary air conditioners, MVAC-1ike appliances, etc.) (Type II certification)

- Very high-pressure equipment with a charge of more than 50 1b (evaporator heating for leak detection and deep evacuation, etc.) (Type II certification)

- Low-pressure equipment (Type III certification)

- Low- and high-pressure equipment (Universal certification).

Technicians servicing MVAC-1ike appliances may choose to become certified by an EPA-approved program under Section 609 of the CAA and 1990 Amendments, and will be considered certified according to the Section 608 requirements. The Oak Ridge National Laboratory Technician Certification Program provides training and certification in all of these categories. A decision on whether the contractors use this program or other training programs is subject to RL Programs approval.

Training Records. The training and development organizations shall maintain EPA-certified training records and confirmations for completion of the general employee awareness training in accordance with Federal and contractor standards and policies.

Technician Certification Program Recordkeeping. Recordkeeping requirements include, but are not 7 imited to, the names and addresses of all individuals taking the certification tests, the scores of all tests administered, and the dates and locations of all tests administered. Certifying programs must send EPA an activity report every 6 months. This report will include the pass/fail rate and testing schedules to allow the EPA to determine the relative progress and success of these programs. If the certifying program believes a test bank 
question needs to be modified, information about that question should also be included.

Programs must issue an identification card to technicians that receive a score of 70 percent or higher on the closed-book certification examination within 30 days. Each card must include the name of the certifying program, the date the organization became a certifying program, a unique number for the certified person, and the following text:

"(Name of person) has been certified as a (Type I, II, III, or Universal, as appropriate) technician as required by 40 CFR 82 , Subpart F."

Technicians certified under 40 CFR 82.161 must keep a copy of their certificate at their place of business. The EPA reserves the right to specify the need for periodic technician recertification.

All records required to be maintained pursuant to these requirements under Subpart $F$ must be kept for at least 3 years unless otherwise indicated by the EPA. Entities that dispose of appliances must keep these disposal and training records on site.

\subsection{CONTAINER, PRODUCT, AND EQUIPMENT LABELING AND MARKING}

This section specifies the labeling and marking requirements for containers and equipment that contain ODSs or are used for refrigerant recovery/recycling.

\subsubsection{Requirement}

Container Labeling. "Labeling of Products Using Ozone-Depleting Substances," Subpart E of 40 CFR 82, requires that containers of Class I or II substances that are introduced into interstate commerce or are shipped off site carry a warning statement. The same warning statement is required for equipment that contains a Class I or II substance and is introduced into interstate commerce or shipped off site.

Recovery and Recycling Equipment. "Certification of Recycling and Recovery Equipment," Paragraph III.G of 40 CFR 82, requires that recovery and recycling equipment manufactured or imported on or after November 15, 1993, be tested and certified by an EPA-approved laboratory or organization. Recovery and recycling equipment purchased before this date is to be verified by the contractor as meeting the intent of the EPA certification. In addition, the EPA requires that equipment and hoses be fitted with low-loss fittings.

All recovery and recycling equipment shall have a label indicating that it is certified and showing which organization tested and certified it. This label is intended to inform both technicians and the EPA that the equipment meets EPA standards. 


\subsubsection{Implementation Process}

Container Labels. Each ODS container that is transported off site as of May 15, 1993, shall display a "WARNING" 1 abel and the standard chemical name of the contents as identified in 40 CFR 82 . The label shall contain the following statement:

"WARNING: Contains (insert the chemical name of the ODS), a substance which harms public health and environment by destroying ozone in the upper atmosphere."

The warning statement must be clearly legible and conspicuous and shall appear in sharp contrast to any background on which it appears. A program to label all onsite ODS-containing materials is currently being evaluated. Such a program is not a regulatory requirement at this time.

Recovery/Recycle Equipment Labels. All certified recovery/recycle equipment shall be labeled as follows:

"This Equipment has been certified by (approved equipment testing organization) to meet the EPA's minimum requirements for recycling or recovery equipment intended for use with (appropriate category of appliance)."

The label is to be applied by the manufacturer or importer of the equipment and shall show the date of manufacture and the serial number of the equipment, if applicable. The label shall be affixed in a readily visible or accessible location, be made of material expected to last the lifetime of the equipment, and be affixed in such a manner that it cannot be removed from the equipment without being damaged.

\subsection{SIGNIFICANT NEW ALTERNATIVES POLICY PROGRAM}

On March 18, 1994, the EPA published its final SNAP Program (59 FR 13044), which provides the EPA's decisions on the acceptability and unacceptability of ODS substitutes. Copies are available from WHC Regulatory Analysis. Refer to Appendix II for a list of SNAP-approved ODSs. This list will be reviewed every 6 months for EPA changes and updated within this plan at least annually.

\subsubsection{Criteria for Review}

The EPA evaluates the acceptability of potential replacements for Class I and II compounds on the following basis:

- Atmospheric effects and related health and environmental impacts

- General population risks from ambient exposure to compounds with direct toxicity and to increased ground-level ozone

- Ecosystem risks

- Occupational risks 
- Consumer risks

- Flammability

- Cost and availability of the substitute.

\subsubsection{Communication of SNAP Decisions to the Public}

Every quarter, the EPA publishes in the Federal Register a complete list of acceptabie and unacceptable alternatives that have been reviewed to date. In the case of substitutes proposed as acceptable with use restrictions, proposed as unacceptable, or proposed for removal from either list, a rulemaking process will ensue. Changes to EPA's SNAP 1.ist will be reviewed and this plan will be updated at least annually.

\subsection{PROCUREMENT}

Another important activity covered under Title VI of the CAA is procurement and its relationship to the SNAP program. Section 613 of the CAA requires the EPA to promulgate regulations requiring each department, agency, and instrumentality of the United States government to conform its procurement regulations to the policies and requirements of Title VI and to maximize the substitution of safe alternatives identified under Section 612 for Class I and II substances. Most Federal procurement is governed by the "Federal Acquisition Regulation" (48 CFR). Currently, the EPA and the Office of Management and Budget are evaluating whether a modification of the "Federal Acquisition Regulation" is necessary to make it comply with the Title VI regulations. Federal agencies, such as DOE, are required to evaluate their procurement regulations to determine compliance with Title VI. On October 22, 1993, EPA published its final procurement regulations at 40 CFR 82 , Subpart D to implement Section 613. Subpart D explicitly states that Class II substances may serve as interim substitutes for Class I substances until a proven-acceptable substitute is determined. This final rule and EO 12843 were promulgated to maximize substitution of safe alternatives and to further implement the policies and requirements of Title VI by Federal agencies.

Procurement will not be involved in the storage of recyclable and excess ODS chemicals. This is addressed in the Operations and Maintenance and Individual Contractor Program sections of this plan. ODS chemicals shall be purchased by certified technicians.

Purchasers. who employ certified technicians may provide to the wholesaler that sells them refrigerants evidence that at least one technician is properly certified. The wholesaler will then keep this information on file and may sel1 refrigerant to the purchaser or his authorized representative even if such purchaser or authorized representative is not a properly certified technician. Procurement will not need to be certified if, at the time of purchase, Procurement provides the wholesaler with information to show that at least one technician on site is properly certified. 


\subsection{PRODUCTS AND SOLVENT USES}

A sitewide inventory of product and solvent uses is currently being conducted by the WHC Pollution Prevention organization. From this inventory, the use(s) of each product identified is to be ascertained and a determination made on the continued need for that particular product and its use. Data are being collected from the procurement records and from the end user of each Hanford Site contractor. A single comprehensive list of these products will provide the basis for ranking alternatives or replacements of ODS-containing products and chemicals, and to eliminate or reduce unnecessary use of these products in compliance with Section 612. Preliminary evaluations indicate that principle uses of ODS-containing products that will extend beyond the year 1995 are solvent cleaners, fire suppression systems, and HVAC systems, including chillers and dryers.

Aerosols. The EPA has essentially banned the manufacture and use of CFCs as aerosol propellants in all but essential applications under Section 610 . These materials and products will be included in the sitewide inventory of product and solvent uses described above.

\subsection{FIRE SUPPRESSION SYSTEMS}

Some fire suppression systems at the Hanford Site use Halon 1301 and 1211. These substances are identified to be phased out on a schedule shown in 40 CFR 82, Subpart A, "Production and Consumption Controls." This section describes activities conducted and planned to address management of fire suppression systems at the Hanford Site. This section includes descriptions of practices and plans that contractors use to manage large fire suppression systems containing Halon and small pieces of equipment used by trained personnel.

\subsubsection{Requirement}

Halons are no longer being manufactured. On May 5, 1993, DOE issued a memorandum and guidance policy entitled Managed Phase Out of Halon Fixed Fire Suppression Systems (DOE 1993). That policy provided direction to begin to collect Halons from large systems removed from service. The materials collected were to be kept in their original containers and either reclaimed or banked on the site for use in systems to be kept in operation. On June 6 , 1993, RL provided the direction to its contractors supporting the DOE policy.

\subsubsection{Implementation Process}

Halon Systems in Facilities Managed by Hanford Contractors. At the Hanford Site, fire suppression is provided through the use of large engineered systems and portable equipment (off-the-shelf equipment). To date, nearly 1,000 ib of Halon 1301 have been removed from service (see Table 1). 
Table 1. Facilities Removed From Service.

\begin{tabular}{|c|c|c|}
\hline Facility & Removal Date & Amount of Halon (1b) \\
\hline $1112-N$ & 1992 & 120 \\
\hline $1129-N$ & 1992 & 240 \\
\hline $1116-N$ & 1993 & 216 \\
\hline 308 & 1993 & 95 \\
\hline $339 A$ & 1994 & 180 \\
\hline $306 \mathrm{~A}$ & 1994 & 107 \\
\hline
\end{tabular}

WHC and ICF KH must evaluate 27 fire suppression systems using Halon for retrofit, replacement, or abandonment. To increase reliability against unintentional release, WHC has reconfigured several systems (see Appendix III). Pacific Northwest Laboratory (PNL) has removed one Halon system from service. WHC manages the Halon bank at the Hanford Site.

Portable Halon Fire Extinguishers. At the Hanford Site, portable fire extinguishers containing $\mathrm{Hal}$ on 1211 are being replaced with carbon dioxide or, preferably, dry chemical extinguishers for most applications. All Halon extinguishers that have been discharged, as well as those scheduled for periodic maintenance, are being removed from service and disposed of properly. Hanford Site contractors no longer purchase new Halon portable fire extinguishers.

\subsection{MOTOR-VEHICLE AIR CONDITIONING SERVICE AND MAINTENANCE}

At the Hanford Site, U.S. Government-owned motor vehicles are provided by RL and the General Services Administration (GSA). ICF KH, under its contract with WHC, maintains the vehicles. This section describes the current practices that ICF KH follows to recover and recycle MVAC refrigerant. This section also describes MVAC refrigerant recovery and recycling activities performed on light-duty trucks, automobiles, heavy mobile construction equipment, and buses used at the Hanford Site.

\subsubsection{Requirement}

The 1990 CAA Amendments require the EPA to promulgate regulations that establ ish standards and requirements for servicing, repairing, and maintaining MVAC. These regulations appear in 40 CFR 82, Subpart B, effective August 13, 1992. They prohibit any person from repairing or servicing MVAC unless that person is properly trained and certified and uses EPA-approved refrigerant recycling equipment. The Subpart B regulations apply to mechanical vapor compression refrigeration equipment used to cool the driver's or passengers' compartment of any motor vehicle. By definition (40 CFR 82.32(d)), hermetically sealed refrigeration systems used in motor vehicles for refrigerated cargo and air conditioning systems on passenger buses using 
HCFC-22 are not regulated under Subpart B. Those systems are regulated under 40 CFR 82, Subpart F, "Recycling and Emissions Reduction."

An additional effect of the regulations is to require that signed certification forms or EPA-approved refrigerant recycling equipment be submitted by RL to EPA Region 10. The regulations also require that refrigerant purchases of more than $201 \mathrm{~b}$ be made only by certified technicians. The certification forms are to be completed by the operations and maintenance personnel using the equipment.

Washington State Dangerous Waste Regulations. As of July 1, 1992, the Washington State Clean Air Act and Federal CAA restricted releases of CFCs during servicing, recycling, or disposal of refrigeration and air conditioning equipment. These materials also are regulated by Federal and State hazardous waste management regulations. Under the Resource Conservation and Recovery Act of 1976 (RCRA), CFCs recovered for disposal, reclamation, or recycling were regulated as toxicity characteristic hazardous waste. However, because gaseous emissions were not included in the Federal definition of a hazardous waste, CFCs that were vented to the atmosphere were not regulated. To encourage hazardous waste generators to cease venting CFCs, the EPA established an interim rule in February 1991 to exempt reclaimed or recycled CFCs from designation as a toxicity characteristic waste. This rule allowed generators to recover the materials without being subject to RCRA manifest and transportation requirements. Therefore, if a CFC is not recycled or reused, it will be subject to the Dangerous Waste Regulations under RCRA.

In contrast to the Federal hazardous waste regulations, the Washington State Department of Ecology (Ecology) originally regulated recovered CFC as a persistent dangerous waste. Intentional venting to the air was therefore prohibited. Ecology changed the requirements for managing recycled and reclaimed CFCs used as heat transfer material in a refrigeration system in totally enclosed heat transfer equipment under WAC 173-303-506. The intent of the regulations was to encourage generators to recover and reclaim the materials, rather than to release them to the atmosphere. The regulations now require generators to retain records of the dates of offsite shipments, the quantity by weight reclaimed/recycled per shipment or batch, the percentage of the total amount of CFC or HCFC wastes reclaimed/recycled per shipment or batch, the manner of disposal for the remaining CFC or HCFC, and the dates of reclamation and recycling. Generators are also required to obtain a signed document from the reclamation facility certifying reclamation. However, they are not subject to the manifest and transportation provisions of the regulations when they are recycling or reclaiming CFC or HCFC used in accordance with the regulations.

\subsubsection{Implementation Process}

Hanford Site MVAC System Practices. The Subpart B regulations apply to the MVAC system service and maintenance activities performed on vehicles meeting the definitions of a motor vehicle. Certified technicians perform recovery and recycling of HCFC-22 from passenger buses using certified equipment dedicated to bus maintenance. Systems in light-duty trucks and automobiles in use on site contain CFC-12 and some passenger buses do not use HCFC-22. When vehicles require MVAC maintenance, certified technicians recover and recycle the refrigerant, repair the systems as needed, then add refrigerant when 
required to ensure that the systems are full. The GSA motor vehicles procured in fiscal year 1994 for delivery to the Hanford Site in fiscal year 1995 will be ordered with air conditioning systems that do not use Class I ODSs.

Technician Certification. The Subpart B regulations prohibit any person from performing any service on a MVAC involving the refrigerant unless the person uses proper equipment and has been trained and certified by an EPA-approved certification program. The training is made up of on-the-job training, training through self-study, or onsite training involving instructors, videos, or a hands-on demonstration. When a person passes the certification test with a score of 84 or better, the training organization provides proof of certification (card or certificate) with a unique technician certification number. Recertification is not required at this time. The EPA reserves the right to specify the need for periodic technician recertification.

Mechanics servicing MVAC units for RL and GSA vehicles at the Hanford Site were trained and certified through the Mobile Air Conditioning Society program as long ago as late 1991. As part of the hiring practices within the Maintenance function servicing motor vehicles, ICF KH is requiring all future employees to have a MVAC technician certification.

Under a systems contract, the vendor that supplies all automotive parts provides refrigerants in 30 - to $120-16$ quantities. Empty refrigerant containers are returned to the vendor for testing and refilling, eliminating a waste stream.

Equipment Certification. Refrigerant recycling equipment must be certified by the EPA or an approved independent standards testing organization. The EPA administrator may determine that equipment purchased before September 4, 1991, that is not certified may be determined to be substantially identical to certified equipment. The equipment manufacturer must submit an application and support documents to the EPA to request a written determination.

At the Hanford Site, ICF KH uses recovery/recycling equipment that has been certified by the Underwriters' Laboratory or determined by the EPA to be substantially identical to certified equipment. Six units are currently in use: three reclamation $\backslash$ recycling units and three small reclamation units suitable for automobile air conditioners. The systems are dedicated to recovery/recycling of CFC-12, HCFC-22, or HFC-134a. In 1993, RL provided signed MVAC recovery/recycling equipment certification forms to the EPA Region 10. Such equipment used on site is listed in Appendix IV.

Recordkeeping for MVAC Refrigerants. Specific recordkeeping is required for persons subject to the Subpart B regulations. RL is considered the owner of all equipment and facilities and the contractors are considered operators. As the owner of approved refrigerant recycling equipment that must be certified, $\mathrm{RL}$ is required to maintain records of the name and address of any facility to which refrigerant is sent. At the Hanford Site, refrigerant is not currentiy sent to outside vendors for reclamation. $\mathrm{RL}$ al so is required to retain records demonstrating that all persons operating the equipment are currently certified. Ecology requires tracking of CFCs and HCFCs. It also requires certain recordkeeping practices (WAC 173-303-506). Personnel performing MVAC refrigerant service, maintenance, or repair must complete log sheets. At the time of service, the certified technician records the date of refrigerant recycling, the vehicle number, the type of refrigerant, the amount of 
refrigerant recycled, the amount of new refrigerant added, and the employee 's name on a "Motor-Vehicle Refrigerant Service Log" (see Figure 1). These records are retained as part of the facility operating record.

Ecology has agreed that the MVAC log system used at the Site's central garage satisfies the recordkeeping requirements 1 isted in the emergency rule promulgated at WAC 173-303-506. This method allows logs to be maintained and updated monthly.

Future Activities. ICF KH Maintenance will evaluate the CFC-12 now in large chiller systems for use in MVAC. Use of the refrigerant will reduce the demand for virgin product, which will become scarce in 1995. In addition, reusing refrigerant in vehicles operating on site will minimize contributions to an excess-refrigerant waste stream.

\subsection{INDIVIDUAL CONTRACTOR PROGRAMS}

\subsection{WHC PROGRAN}

WHC is the Engineering and Operations (E\&O) contractor for RL and is responsible for maintaining equipment and facilities on a large portion of the Hanford Site. Morrison Refrigeration and ICF KH subcontractors are responsible for maintaining refrigerant systems at WHC facilities. RL manages the contract held with Morrison Refrigeration, using the services of a contract manager provided through ICF KH.

WHC recently established a task team to address management of refrigerant systems. The task team is composed of facility maintenance, Quality Assurance, and ICF KH refrigeration maintenance personnel and is responsible for addressing all logistical and technical issues associated with the repair, replacement, or abandonment of refrigerant systems under the control of WHC.

WHC and ICF KH management recently determined that the service, maintenance, and repair of most refrigerant systems and equipment (not including small appliances) containing ODSs will become an ICF KH responsibility. A memorandum of agreement (MOA) between ICF KH and the WHC facilities management will be established that describes the service to be performed, service priorities, access and work control requirements, and reporting responsibilities. This MOA will be established in fiscal year 1995.

\section{Implementation Process}

Operations, Maintenance, and Control of Refrigerant Systems Containing ODSs. WHC currently uses EPA-approved recovery and recycling devices operated by EPA-certified craft personnel to service, repair, and maintain large refrigerant systems. However, once the MOA with ICF KH takes effect in 1994, ICF KH will take possession of refrigerants and recovery and recycling equipment at each WHC/ICF KH facility.

Training and Certification. WHC has established a module to address personnel exposure to refrigerants within the general employee awareness training program. The WHC Environmental Training Programs organization has already introduced Title VI requirements into the Phase I Manager/Environmental 


\section{MOTOR-VEHICLE REFRIGERANT SERVICE LOG}

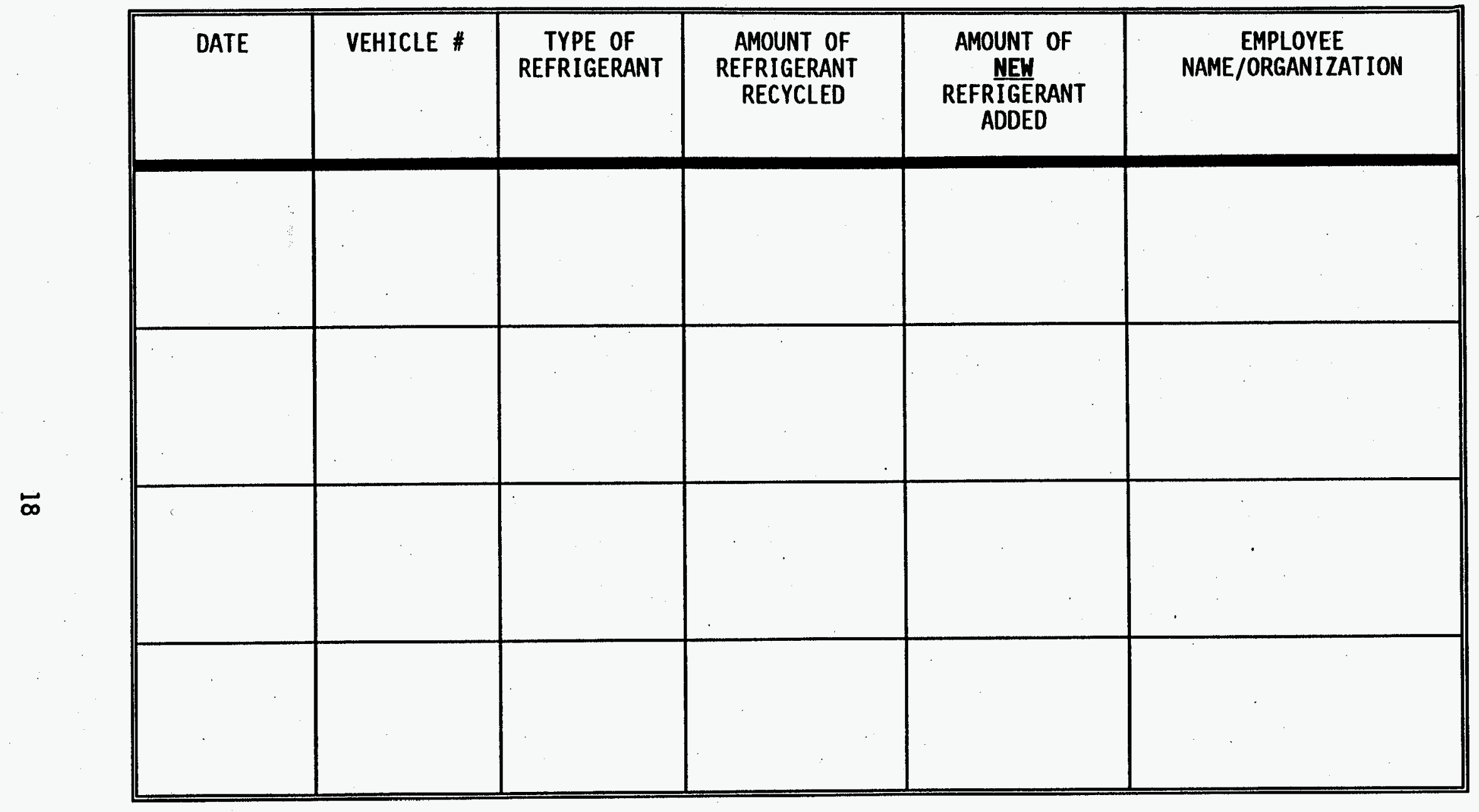


Compliance Officer Training, and is planning to introduce the most recent changes and additional CAA 1990 Amendment requirements into the refresher Manager/Environmental Compliance Officer Training during its renewal and update in April 1995.

Container, Product, and Equipment Labeling and Marking. WHC has established control of ODS purchases by establishing a review process within the procurement organization. An individual within the Pollution Prevention organization independently reviews every purchase requisition to ensure that, wherever possible, suitable alternatives are procured in place of commercial products and solvents containing ODSs.

WHC operates the excess yard at the Hanford Site and will label all refrigerant systems that contain ODSs before they are declared excess/surplus and before they are reintroduced into interstate commerce.

\subsection{ICF KH SUPPORT TO WHC}

\section{Implementation Process}

Operations, Maintenance, and Control of Refrigerant Systems Containing ODSs. ICF KH uses trained, certified technicians to repair, service, and maintain refrigeration systems. When the MOA is established with each facility, ICF KH will assume control of the recovery and recycling equipment and associated refrigerant inventory.

As a subcontractor to WHC, ICF KH has established a database of refrigerant units present in facilities within its responsibility. ICF KH will compile data on these units for reporting to Ecology under the provisions of the Clean Air Act Title V Air Operating Permit. The database will also track stocks of refrigerants to allow maximum reuse and to el iminate costly purchases of refrigerants. ICF KH is working to establish an inventory control system to ensure that refrigerants are available as needed and that unnecessary purchases of virgin material are avoided.

Under the current contract with WHC, ICF KH will continue to maintain the Hanford Site fleet-vehicle air conditioning systems for RL vehicles. ICF KH will service GSA vehicles unless the GSA determines that service will be. performed by others.

The ICF KH Energy Management organization will review all capital projects with a total value of more than $\$ 5$ million that are intended to replace or retrofit existing HVAC equipment with new equipment for IHEM funding. Projects that Energy Management identifies as having a savings-toinvestment ratio greater than unity and a payback period of less than 10 years will be implemented.

\subsection{PACIFIC NORTHWEST LABORATORY PROGRAM}

PNL manages research and development facilities for RL. The facilities include refrigerant systems, equipment, and chemicals that contain ODSs. This section describes activities conducted within PNL to support management and phase-out of ODSs. 


\section{Implementation Process}

Operations, Maintenance, and Control of Refrigerant Systems Containing ODSs. PNL maintains a crew of EPA-certified technicians who use EPA-certified equipment to recover and reclaim refrigerants from HVAC systems and refrigeration systems. Of approximately 250 pieces of equipment containing ODSs, only 12 have more than $50 \mathrm{lb}$ of capacity, making them subject to 40 CFR 82 Subpart $F$ reporting requirements. In accordance with the regulatory requirements, PNL will track only those pieces of equipment with more than $50 \mathrm{ib}$ of capacity. WHC/ICF KH is tracking appliances with a capacity of $2 \mathrm{lb}$ or more for best management practice and accountability. PNL trained/certified technicians repair small appliances containing ODSs when they experience mechanical failure to avoid the cost of replacement.

The PNL maintenance organization keeps ready stocks of refrigerants in a central location for use by technicians servicing equipment systems. To track service histories for approximately 250 pieces of equipment, the PNL maintenance organization has entered information about each system into a database. When the Hanford Site refrigerant equipment database is established, PNL will provide leak rates and quantities to the WHC database administrator for inclusion in the Air Operating Permit periodic reports, as required.

Energy Conservation Measures. PNL evaluates all refrigerant system replacements to determine if the projects meet the DOE requirements for energy conservation.

Training and Certification. Technicians servicing refrigeration equipment within PNL-managed facilities are trained and are currently certified by the Refrigeration Service Engineering Society (RSES). PNL has transmitted a certification to EPA Region 10 that equipment used to recover and recycle refrigerants meets Subpart $F$ requirements.

Container, Product, and Equipment Labeling and Marking. PNL will comply with the container labeling requirements set forth in 40 CFR 82 Subpart $E$ when containers are introduced into interstate commerce. Equipment used for recovering and/or recycling of ODSs will have labeled containers.

Procurement of Alternatives for ODSs. PNL personnel use three methods to acquire materials and equipment for use in DOE facilities:

- The centralized procurement system managed by WHC

- The PNL purchasing organization

- Petty cash disbursements.

PNL will comply with Executive Order 12843 and avoid purchasing products containing ODSs.

Chemicals containing ODSs that are used in the laboratories and are purchased through the first two methods are tracked using a Chemical Inventory System. PNL Laboratory Safety will issue a directive to researchers to avoid purchasing small quantities of materials containing ODSs and to seek replacements. 


\subsection{BECHTEL HANFORD, INC. PROGRAM}

Bechtel Hanford, Inc. (BHI) is the Environmental Restoration contractor (ERC) for the Hanford Site. The ER contract calls for turnover of RCRA inactive treatment, storage, and disposal (TSD) facilities and surplus facilities to be decontaminated and decommissioned (D\&D) during the next 5 years. Additional TSD unit closures may be added to the program as facilities are transitioned by the E\&O contractor.

Operations, Maintenance, and Control of Refrigerant Systems Containing ODSs. As facilities are transitioned to D\&D work under the ERC, BHI will assess and inventory ODS-containing products, refrigeration systems, and recycle/recovery equipment. As facilities are deactivated and transitioned to D\&D, ODScontaining systems will be removed from the facility by the E\&O contractor before the facility is transferred to BHI. BHI will periodically submit information for reporting purposes to the custodian of the sitewide central inventory database.

Training and Certification. The BHI technician servicing, maintaining, and repairing refrigerant systems is properly trained and certified by the Educational Foundation of the RSES pursuant to. Revised Code of Washington (RCW) 70.94. This program is awaiting EPA approval on or before October 1994. Refrigerants containing ODSs will be recycled and reused in accordance with the sitewide implementation plan. Technician training records will be maintained in accordance with Section 3.4 of this plan.

BHI employees will receive awareness training through the HGET program (see Section 3.4).

Container, Product, and Equipment Labeling and Marking. Labeling will be in accordance with the requirements set forth in Section 3.5 of this plan.

BHI Procurement will notify end users of ODS alternative product selection, identify products that are to be discontinued as stock items, identify products that have limited distribution, and ensure that new purchases contain only acceptable alternatives identified in the current SNAP list (see Section 3.6).

\subsection{HANFORD ENVIRONMENTAL HEALTH FOUNDATION PROGRAM}

The Hanford Environmental Health Foundation (HEHF) provides medical services for employees on the Hanford Site. As part of that responsibility, HEHF conducts personnel monitoring for WHC and ICF KH. HEHF operations are housed in facilities managed by WHC or acquired by WHC for HEHF. Service, repair, or maintenance of refrigeration equipment is conducted by WHC or its subcontractors.

HEHF uses small quantities of ODSs when required to comply with laboratory protocols. These ODSs are used as laboratory solvents or as part of established laboratory procedures. HEHF has reduced the amounts of ODSs required to perform analyses threefold from 1990 to 1993. Efforts will continue to minimize use of ODSs and to avoid any unnecessary purchases of them. 


\subsection{COMPLIANCE VERIFICATION}

Each contractor is required to perform an independent verification, i.e., quality assurance, for compliance with this plan. An audit, surveillance, and assessment program needs to be established to verify compliance. Each program will be established in accordance with DOE Order 5700.6C (DOE 1991).

\subsection{GLOSSARY}

The following definitions and terms are derived from 40 CFR 82 as it applies to the Hanford Site.

Appliance. Any device that contains and uses a Class I or Class II ODSs (see Table 1) as a refrigerant and is used for household or commercial purposes, including air conditioners, refrigerators, chillers, water fountains, ice makers, or freezers.

Approved. Approval received from the EPA pursuant to 40 CFR 82.

Class I Substance. Any controlled substance listed in Appendix A of Subpart A, 40 CFR 82 (see Table 2). Class I substances are classified as having the most harmful effect on the ozone layer.

Class II Substance. Any controlled substance listed in Appendix B of Subpart A, 40 CFR 82 (see Table 2). Class II substances are classified as having a less harmful effect on the ozone layer than Class I substances.

Consumption. The production plus imports minus exports of a controlled substance (other than transshipments, or recycled or used controlled substances).

Controlled Product. A product that contains a controlled substance listed as Class I, Group I or II and that belongs to one or more of the following six categories of products:

- Automobile and truck air conditioning units (whether incorporated in vehicles or not)

- Domestic and commercial refrigeration and air conditioning/heat pump equipment (whether containing controlled substances as a refrigerant and/or insulating material of the product)

- Aerosol products

- Portable fire extinguishers

- Insulation boards, panels, and pipe covers

- Prepolymers.

Controlled products include, but are not limited to, those products 1 isted in Appendix D of 40 CFR 82 . 
Controlled substance. Any substance containing either a Class I or a Class II substance, listed in Table 2, whether existing alone or in a mixture. This excludes any such substance or mixture that is in a manufactured product other than a container used for the transportation or storage of the substance or mixture.

Chlorofluorocarbon (CFC). Any substance listed as Class I, Group I or Class I, Group III in Appendix A of 40 CFR 82, Subpart A (see Table 2).

Consumer. The ultimate purchaser, recipient, or user of a product.

Container. The immediate vessel in which a controlled substance is stored or transported.

Certified. Any equipment and/or personnel certified by an EPA-approved testing organization to meet the standards set forth in 40 CFR 82 .

Disposal. Any process leading to depositing, dumping, or placing any discarded appliance for discharge, deposit, or dumping into or on any 1 and or water; disassembly of any appliance and reuse of its discarded component into or on any land or water.

Hydrochlorofluorocarbon (HCFC). Any substance listed as Class II in Appendix B of 40 CFR 82, Subpart A (see Table 2).

Major Maintenance, Service or Repair. Any maintenance, service, or repair involving the removal of any or all of the following appliance components: compressor, condenser, evaporator, or auxiliary heat exchanger coil.

Motor-Vehicle Air Conditioner (NVAC). Mechanical vapor compression refrigeration equipment used to cool the driver's or passengers' compartment of any motor vehicle. This definition is not intended to encompass the hermetically sealed refrigeration systems used on motor vehicles for refrigerated cargo and the air conditioning systems of passenger buses using HCFC-22 refrigerant.

Opening an Appliance. Any service, maintenance, or repair on an appliance that could be reasonably expected to release refrigerant from the appliance to the atmosphere unless the refrigerant was previously recovered from the appliance.

Ozone-Depleting Substance (ODSs). Any Class I or II substance or any azeotropic mixture containing a Class I or II substance(s) is considered to be an ODS.

Ozone Depletion Potential. The factor established by Section 602 of the CAA and 1990 Amendments, which defines the relative ozone depletion potential of substances using CFC-11 (refrigerant-11 or $R-11$ ) as a reference.

Person. Any individual or legal entity, including an individual, corporation, partnership, association, state, municipality, political subdivision of a state, Indian Tribe, and any agency, department, or instrumentality of the United States and any officer, agent, or employee thereof. 
Release. Emit into the environment during the manufacture, use, storage, or disposal of a product.

Reclaim Refrigerant. Reprocess refrigerant to at least the purity specified in the Air Conditioning and Refrigeration Institute (ARI) Standard 700-1988, "Specifications for Fluorocarbon Refrigerant" (ARI 1988), and to verify this purity using the analytical methodology prescribed in the ARI standard. In general, reclamation involves the use of processes or procedures available only at a reprocessing or manufacturing facility.

Recover Refrigerant. Remove refrigerant in any condition (i.e. damaged or impure) from a system for storage, recycling, reclamation, or transportation.

Recycle Refrigerant. Extract and clean recovered refrigerant for reuse without verifying compliance with all of the requirements for reclamation. In general, recycled refrigerant is refrigerant that has been cleaned using oil separator(s) and single or multiple passes through devices and refrigerant (MVAC) and replaceable core filter-drier(s), which reduce moisture, acidity, and particulate matter.

Substitute or Alternative. Any chemical, product substitute, or alternative manufacturing process, whether existing or new, intended for use as a replacement for a Class I or II compound.

Type Size. The actual height of the printed image of each capital letter as it appears on a label.

Technician. Any person who performs maintenance, service, or repair that could reasonably be expected to release Class I or II substances from appliances into the atmosphere, including but not limited to installers, contractor employees, in-house servicing personnel, and, in some cases, owners. Technician also means any person disposing of appliances except for small appliances.

Used or Recycled Controlled Substance. Controlled substances that have been recovered from their intended-use systems.

Harning Labe1. The warning statement required by Section 611 of the CAA and 1990 Amendments. The term warning statement shall be synonymous with warning label for clean-air purposes. 
Table 2. Class I and II ODSs.

\begin{tabular}{|c|c|c|c|c|c|c|}
\hline \multicolumn{7}{|c|}{ Class I } \\
\hline Group 1 & Group II & Group III & Group IV & Group V & Group VI & Group VII \\
\hline $\begin{array}{l}\text { CFC-11 } \\
\text { CFC-12 } \\
\text { CFC-113 } \\
\text { CFC-114 } \\
\text { CFC-115 } \\
\text { In industry, } \\
\text { these are: } \\
R-11 \\
R-12 \\
R-113 \\
R-114 \\
R-115\end{array}$ & $\begin{array}{l}\text { Halon-1211 } \\
\text { Halon-1301 } \\
\text { Halon-2402 }\end{array}$ & $\begin{array}{l}\text { CFC-13 } \\
\text { CFC-111 } \\
\text { CFC-112 } \\
\text { CFC-211 } \\
\text { CFC-212 } \\
\text { CFC-213 } \\
\text { CFC-214 } \\
\text { CFC-215 } \\
\text { CFC-216 } \\
\text { CFC-217 }\end{array}$ & $\begin{array}{l}\text { Carbon } \\
\text { tetrachloride }\end{array}$ & $\begin{array}{l}\text { Mothyl } \\
\text { chloroform } \\
\text { (1. } 1,1 \\
\text { trichloroethane) }\end{array}$ & Methyl bromide & $\begin{array}{l}\text { Hydrobromo- } \\
\text { fluorocarbons }\end{array}$ \\
\hline \multicolumn{7}{|c|}{ Class II } \\
\hline HCFC-21 & \multicolumn{2}{|c|}{ HCFC-22 } & HCFC-31 & HCFC-121 & HCFC-122 & HCFC-123 \\
\hline HCFC-124 & HCFC-131 & HCFC-132 & HCFC- 133 & HCFC 141 & HCFC-141B & \\
\hline HCFC 142 & HCFC-142B & HCFC-221 & HCFC- 222 & HCFC-223 & HCFC-224 & \\
\hline HCFC-225CA & $\mathrm{HCFC}-225 \mathrm{CB}$ & HCFC-226 & HCFC-231 & HCFC- 232 & HCFC- 233 & \\
\hline HCFC-234 & HCFC-235 & HCFC-241 & HCFC-242 & HCFC-243 & HCFC-244 & \\
\hline HCFC-251 & HCFC-252 & HCFC-253 & HCFC-261 & HCFC-262 & HCFC-271 & \\
\hline
\end{tabular}

\subsection{REFERENCES}

40 CFR 82, "Protection of Stratospheric Ozone," Code of Federal Regulations, as amended.

48 CFR 2, "Federal Acquisition Regulations," Code of Federal Regulations, as amended.

59 FR 13044, 1994, "SNAP Program," Federal Register, Vol. 52, pp. 13044-, March 1994.

ARI, 1988, Specifications for Fluorocarbon Refrigerants, ARI Standard 700-1988, Air Conditioning and Refrigeration Institute:

Clean Air Act Amendments of 1990, Public Law 101-549, 42 USC 7401-7671Q.

Clean Air Act of 1963, Public Law 88-206, as amended 42 USC 7401 et seq.

Davis-Bacon Act, as amended, Title 48 Stat 1494, 80 USC 276A et seq.

DOE, 1987, Project Management System, DOE Order 4700.1, U.S. Department of Energy, Washington, D.C.

DOE, 1989, General Design Criteria, DOE Order 6430.1A, U.S. Department of Energy, Washington, D.C.

DOE, 1991; Quality Assurance, DOE Order 5700.6C, U.S. Department of Energy, Washington, D.C. 
DOE, 1993, Managed Phase Out of Halon Fixed Fire Suppression Systems, letter to contractors, Correspondence Number 94-RPA-153, U.S. Department of Energy, Washington, D.C.

DOE, 1994, Recommended Approaches to Management of Refrigerants at DOE Facilities, U.S. Department of Energy, Office of Environmental Guidance (EH-23), Washington, D.C.

EPA, 1993, Procurement Requirements and Policies for Federal Agencies for Ozone-Depleting Substances, Executive Order 12843, U.S. Environmental Protection Agency, Washington, D.C.

Montreal Protocol on Substances that Deplete the Ozone Layer, Protocol to the Vienna Convention, September 1987.

RCW 70.94, "Solid Waste Management--Reduction and Recycling," Revised Code of Washington, as amended.

Resource Conservation and Recovery Act of 1976, 42 U.S.C. 6901 et seq.

WAC 173-303, 1990, "Dangerous Waste Regulations," Washington Administrative Code, as amended.

Washington Clean Air Act of 1967, RCW 70.94, as amended, Revised Code of Washington, 01 ympia, Washington.

Wisness, S. H., 1994, Correspondence Number 94-RPA-153, 1etter to A. L. Trego et al., U.S. Department of Energy, Richland Operations Office, Richland, Washington. 
DOE/RL-94-86

APPENDIX I

MAINTENANCE FORMS 
DOE/RL-94-86

This page intentionally left blank. 


\section{INVENTORY FORM}

\section{SYSTEM RESPONSE PRIORITY: Identify initial service response time required. In addition, identify any equipment down time limits and basis. \\ SERVICE ORGANIZATION: \\ The organization code of the organization currently responsible for service, repair, and documentation. \\ EQUIPMENT ID NUMBER: \\ Existing facility assigned unique identifier presently assigned to the equipment. \\ DATA BASE ID NUMBER: \\ Site-Wide unique number to be assigned by the central work group. \\ MANUFACTURER INFORMATION: Include for single items of equipment to the best ability of the facility.}

For small appliances (under 5 pounds of refrigerant) leave Manufacturer information blank. Instead. enter equipment type code and a total count of units for the building on the EQUIPMENT TYPE line. Also, enter FREON TYPE and estimated total AMOUNT IN SYSTEM.

INSTALLATION DATE:

BTU/CAPACITY RATING:

EXPECTED SERVICE FREQUENCY:

COMMENTS:
This is to be provided to determine operating age and remaining service life of single items of equipment.

Provide either. BTU or tonnage rating.

List all expected service and the frequency expected. Continue in comments if necessary.

In comments section address:

- Recovery containers, quantities and locations.

- Special access needs (1adders. scaffolding, zones, clearances, etc).

- Any other noteworthy items or issues that pertain to PM or service of equipment. 
BLDG MNGR.

AREA

BUILDING NUMBER

SYSTEM RESPONSE PRIORITY

EQUIP. LOCATION ROOM \# ROOF ( ) GROUND ( ) OTHER EQUIPMENT ID NUMBER DATA BASE ID NUMBER MANUFACTURER OF EQUIPMENT MANUFACTURER MODEL NUMBER MANUFACTURER SERIAL NUMBER INSTALLATION DATE BTU / CAPACITY RATING FREON TYPE $R-11$ - $R-12$ - R-22 - OTHER (LIST TYPE) AMOUNT IN SYSTEM LBS. $0 z$. $(\mathrm{MM} / \mathrm{DD} / \mathrm{YY})$ EQUIPNENT TYPE NUMBER

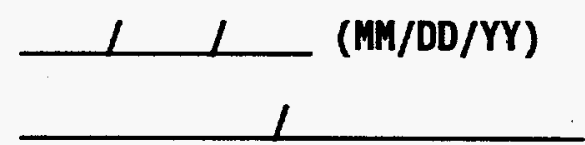
SERVICE ORG 
AREA BUILDING NUMBER

SERVICE ORG

EQUIPMENT ID NUMBER

DATA BASE ID NUMBER

SERVICE DATE

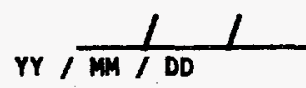

INVOICE/WK PKG \#

CRAFT NAME

CUSTOMER

TOTAL VOLUME REMOVED

OZS REFRIGERANT TYPE

TOTAL VOLUME RETURNED

ozs

VACUUM

TOTAL VOLUME ADDED

0zs

OIL REMOVED

Ozs

TOTAL VOLUME OF SYSTEM

Ozs

TOTAL CHARGE

Ozs

LEAK REPAIRED

YES( )

NO( )

REFRIGERANT STOCKPILED

YES( )

NO( )

\section{COMMENTS:}


DOE/RL-94-86

This page intentionally left blank. 
DOE/RL-94-86

\section{APPENDIX II}

ACCEPTABLE ODSS 
DOE/RL-94-86

This page intentionally left blank. 
DOE/RL-94-86

\section{APPENDIX II}

\section{ACCEPTABLE ODSS}

The following refrigerants are acceptable to the EPA as of March 18, 1994.

$R-22$

$R-123$

$R-124$

R-134a

$R-152 a$

$\mathrm{R}-200 \mathrm{~b}$

$\mathrm{R}-227$

R-290

R-401a

$R-401 b$

$R-401 c$

$R-402 a$

$R-402 b$

$\mathrm{R}-404 \mathrm{a}$

$R-406 a$ (drop-in replacement for CFC-12)

$\mathrm{R}-507$

$\mathrm{R}-600$

Butane

R-717

Ammonia

$\mathrm{R}-744$

Carbon Dioxide

R-1270 Propane

The following product and solvent uses are acceptable to the EPA as of March 18,1994 .

aqueous cleaners for metals cleaning

straight organic solvent cleaning (with terpenes, alcohols,

trichloroethylene, etc.)

vanishing oils

volatile methyl siloxanes

perfluorocarbons

HCFC $141 b$ and its blends 
DOE/RL-94-86

dibromomethane

HCFC 123

HCFC 225

saturated light hydrocarbons (aerosols)

dimethy 1 ether

HCFC 152a (blends)

HCFC 125

HCFC 134a

HCFC 227 
DOE/RL-94-86

APPENDIX III

HALON 1301 PHASE-OUT PROGRAM

III-1 


\section{DOE/RL-94-86}

This page intentionally left blank. 


\section{APPENDIX III}

\section{HALON 1301 PHASE-OUT PROGRAM}

A description of each Halon 1301 system still in service as of April 1, 1994 follows. Proposed action(s) for each Halon system that will be taken by the responsible management in phasing out these systems is included with each description.

1) FACILITY: Building 105N, Control Room

Halon

Content: Main- 1536"

Basis: Property protection of shutdown nuclear facility. Scheduled for near-term decommissioning.

Phase-out: For the short term, the system will be maintained in automatic suppression mode activated by cross-zoned smoke detectors. Management is pursuing the applicability of an equivalency that would permit the deactivation of the Halon

Target

Date: system.

Actionee:

$4 / 31 / 95$
WHC/RR

2) FACILITY: Building $105 \mathrm{~N}$, Room 6

Halon

Content: Main- 2632"; Reserve- 2632"

Basis: Property protection of shutdown nuclear facility.

Scheduled for near-term decommissioning.

Phase-out: For the short term, the system will be maintained in automatic suppression mode activated by cross-zoned smoke detectors. Management is pursuing the applicability of an equivalency that would permit the deactivation of the Halon

Target system.

Date:

$4 / 31 / 95$

Actionee: WHC/RR

3) FACILITY: Building 182N, Control Room

Haion

Content: Main- $127^{*}$; Reserve- $127^{*}$

Basis: Property protection of shutdown highlift pumphouse.

Scheduled for near-term decommissioning.

Phase-out: Management has submitted a request for devaluation of this building and its contents to RL. If the devalued value warrants, the Halon system will be deactivated; if not, the

Target

Date: phase-out options will be reevaluated.

Actionee: WHC/RR 
4) FACILITY: Building $184 \mathrm{~N}$, Control Room

Halon

Content: Main- 120*: Reserve- 120*

Basis: Property protection of shutdown power house.

Scheduled for near-term decommissioning.

Phase-out: Management has submitted a request for devaluation of this building and its contents to RL. If the devalued value warrants, the Halon system will be deactivated; if not, the

Target phase-out options will be reevaluated.

Date: $\quad 12 / 31 / 94$

Actionee: $\mathrm{WHC} / \mathrm{RR}$

5) FACILITY: Building 202A (PUREX), East Crane

Halon

Content: Main- 53"

Basis: Life safety of operator while over PUREX canyon.

Plant scheduled for near-term deactivation.

Crane needed for plant deactivation.

Phase-out: This system has been reconfigured for manual release. No other actions are anticipated through the operational life

Target

Date: of PUREX.

Completed
WHC/OPS

6) FACILITY: Building 202A (PUREX), West Crane

Halon

Content: Main- 45*

Basis: Life safety of operator while over PUREX canyon

Plant scheduled for near-term deactivation.

Crane needed for plant deactivation.

Phase-out: This system has been reconfigured for manual release. No other actions are anticipated through the operational life

Target

Date: of PUREX.

Actionee: Completed

WHC/OPS 
7) FACILITY: Building 202A (PUREX), N-Ce11

Halon

Content: Main-430*; Reserve- 430"

Basis: $\quad$ Property protection of contaminated compartment.

$\mathrm{N}-\mathrm{Ce} l 1$ scheduled for deactivation by $6 / 96$.

Phase-out: For the short term, this system will be maintained in an automatic suppression mode activated by single zone heat detectors. On completion of the $\mathrm{N}$-Cell cleanup, the related Halon system will be deactivated and removed.

Target

Date:

$6 / 30 / 96$

Actionee: WHC/OPS

8) FACILITY: Building 222S, Counting Room B-1A

Hal on

Content: Main- 304"

Basis: Room property protection in a building fully equipped with sprinklers.

Facility is essential asset for duration of site cleanup.

Phase-out: For the short term, this system will be maintained in an automatic suppression mode activated by cross-zoned smoke detectors. The system will be evaluated to determine the most appropriate alternative suppression system. The Halon

Target system will then be deactivated and replaced.

Date: $\quad 12 / 31 / 94$ (Evaluation complete)

Actionee: WHC/OPS

9/30/96 (System replacement)

9) FACILITY: Building 222S, Counting Room B-1B

Halon

Content: Main- 88*

Basis: Room property protection in a building fully equipped with sprinklers.

Facility is an essential asset for duration of site cleanup.

Phase-out: For the short term, this system will be maintained in an automatic suppression mode activated by cross-zoned smoke detectors. The system will be evaluated to determine the most appropriate alternative suppression system. The Halon

Target system will then be deactivated and replaced.

$\begin{array}{lrl}\text { Date: } & 12 / 31 / 94 & \text { (Evaluation complete) } \\ 9 / 30 / 96 & \text { (System replacement) }\end{array}$

Actionee: WHC/OPS 
10) FACILITY: Building 222S, Counting Room B-1F\&1G

Halon

Content: Main- 319*; Reserve- $319^{\#}$

Basis: Room property protection in a building fully equipped with sprinklers.

Facility is an essential asset for duration of site cleanup.

Phase-out: For the short term, this system will be maintained in an automatic suppression mode activated by cross-zoned smoke detectors. The system will be evaluated to determine the most appropriate alternative suppression system. The Halon

Target

Date: system will then be deactivated and replaced.

Actionee: WHC/OPS

$12 / 31 / 94$ (Evaluation complete)

9/30/96 (System replacement)

11) FACILITY: Building 234-52 (PFP), Remote Mechanical C-Line

Halon

Content: Main- 338*; Reserve- 338"

Basis: Property protection of a facility fully equipped with sprinklers.

Facility planned for near-term deactivation.

Phase-out: For the short term, this glovebox suppression system will be maintained in an automatic suppression mode activated by a single-zone heat detection system. On final cleanup and deactivation of the gloveboxes, the system will be evaluated for deactivation and removal.

Target

Date:

Actionee: WHC/OPS

12) FACILITY: Building 243-G4 (GROUT), Control Room

Halon

Content: Main- 196"

Basis:

Property protection of Grout Facility, which is in standby mode.

Remote location with insufficient fire protection water.

Phase-out: The system will be maintained in an automatic suppression mode activated by cross-zoned smoke detectors unt i either the facility is deactivated or an order is given to deactivate the Halon. Should the Grout Facility be assigned a mission that requires use of this structure, the Haion system will be replaced by an acceptable alternative.

Target

Date:

To be determined

Actionee: WHC/TWR 
13) FACILITY: Building 243-G6 (GROUT), Switchgear Room

Halon

Content: Main- 88\#

Basis: Property protection of Grout Facility which is in standby mode:

Remote location with insufficient fire protection water.

Phase-out: The system will be maintained in an automatic suppression mode activated by cross-zoned smoke detectors until either the facility is deactivated or an order is given to deactivate the Halon. Should the Grout Facility be assigned

Target a mission that requires use of this structure, the Halon

Date: system will be replaced by an acceptable alternative.

Actionee: WHC/TWR

14) FACILITY: Building 251W, Electrical Substation \& Dispatch Center

Halon

Content: Main- $877^{\#}$

Basis: Property protection of high-value structure.

Facility essential for long-term power distribution.

Phase-out: This system consists of six individual Halon subsystems that are configured to discharge simultaneously within the substation. Because this is a continuously staffed facility, the system has been reconfigured for manual release. After an evaluation has been conducted to determine an appropriate alternative means of suppression,

Target

Date: the system will be deactivated and replaced.

Actionee: ICF KH/UTL

$6 / 31 / 95$ (Evaluation Complete)

9/30/96 (System Replaced)

15) FACILITY: Building 292AB (PUREX), Vent Stack Instrumentation Building

Halon

Content: Main- 544"; Reserve- 544"

Basis: $\quad$ Property Protection of remote structure.

Purex scheduled for near-term deactivation.

Facility is essential for PUREX deactivation.

Phase-out: For the near term, this system will be maintained in an automatic suppression mode activated by cross-zoned smoke detectors. Final system disposition/phase-out will be dictated by the final deactivated PUREX end-stage. There will be no committed effort at this time to evaluate the

Target final resolution.

Date:

To be determined

Actionee: WHC/OPS 
16) FACILITY: Building 2701ZA (PFP), Patrol CAS

Haion

Content: Main- 319"; Reserve- 319"

Basis: Property protection of Computer Facility.

Facility required through deactivation of PFP.

Phase-out: For the short term, because this facility is continuously staffed, it is being reconfigured for manual release. After an evaluation has been conducted to determine an appropriate alternative means of suppression, the Halon system will be

Target deactivated and replaced.

Date:

4/30/95 (Evaluation Complete)

Actionee: WHC/OPS

17) FACILITY: Building 2704Z, Plutonium Record Vault

Halon

Content: Main- 33"

Basis:

Program Impact and QA Files.

Phase-out: For the short term, the system will be maintained in an automatic suppression mode activated by cross-zoned smoke detectors. After an evaluation is conducted to determine an appropriate alternative means of suppression, the Halon

Target system will be deactivated and replaced.

Date:

$4 / 30 / 95$ (Evaluation Complete)

Actionee: WHC/OPS

$$
\text { 4/30/96 (System Replaced) }
$$

18) FACILITY: Building 403, FSF Control Room

Halon

Content: Main- 160*

Basis: Property protection of computer facility.

Phase-out: The system will be maintained in an automatic suppression mode activated by cross-zoned smoke detectors until either the facility is deactivated or an order is given to

Target

Date: deactivate the Halon.

Actionee: WHC/OPS

3/99 (Facility Deactivation) 
19). FACILITY: Building 4703, Room 110 Computer Facility

Halon

Content: Main- 278*; Reserve- 278*

Basis: Property protection of computer facility.

Phase-out: The system will be maintained in an automatic suppression mode activated by cross-zoned smoke detectors until either the facility is deactivated or an order is given to

Target

Date: deactivate the Halon.

Actionee: WHC/OPS

20) FACILITY: Building 4703, Room 135 Computer Facility

Halon

Content: Main- 143*; Reserve- 143"

Basis: Property protection of computer facility.

Phase-out: The system will be maintained in an automatic suppression mode activated by cross-zoned smoke detectors until either the facility is deactivated or an order is given to

Target deactivate the Halon.

Date:

Actionee: WHC/OPS

$3 / 99$ (Facility Deactivation)

21) FACILITY: Building 4721, Turbine-Generator Enclosure

Hal on

Content: Main- 162"; Reserve- $162^{\#}$

Basis: Property protection for programmatic impact.

Phase-out: The system will be maintained in an automatic suppression mode activated by cross-zoned smoke detectors unt il either the facility is deactivated or an order is given to

Target deactivate the Halon.

Date:

$3 / 99$ (Facility Deactivation)

Actionee: WHC/OPS

22) FACILITY: Building 491E, Computer Room

Halon

Content: Main- 220"; Reserve- 220\#

Basis: $\quad$ Property protection of computer facility.

Phase-out: The system will be maintained in an automatic suppression mode activated by cross-zoned smoke detectors until either the facility is deactivated or an order is given to

Target deactivate the Halon.

Date:

$3 / 99$ (Facility Deactivation)

Actionee: WHC/OPS 
23) FACILITY: Building 747, HEPA Filter Test Lab

Halon

Content: Main $-15^{*}$

Basis: Property protection.

Long-term mission testing of Site HEPA filters.

Phase-out: This system is being evaluated for identification of, and

Target

Date: $\quad 4 / 1 / 95$

Actionee: ICF KH/MTN

24) FACILITY: Federal Building, East ADP Room

Halon

Content: Main $-1422^{\#}$

Basis:

Property protection of computer facility.

Facility has long-term mission.

Phase-out: For the short term, because this facility is continuously staffed, it is being reconfigured for manual release. After an evaluation has been conducted to determine an appropriate alternative means of suppression, the system will be

Target deactivated and replaced.

Date:

9/30/94 (Evaluation planned for completion)

Actionee: ICF $\mathrm{KH} / \mathrm{LL}$ 9/30/96 (System replacement)

25) FACILITY: Federal Building, West ADP Room

Halon

Content: Main $-1167^{*}$

Basis: Property protection of computer facility.

Facility has long-term mission.

Phase-out: For the short term, because this facility is continuously staffed, it is being reconfigured for manual release. After an evaluation has been conducted to determine an appropriate a) ternative means of suppression, the system will be

Target deactivated and replaced.

Date:

9/30/94 (Evaluation planned for completion)

Actionee: ICF $\mathrm{KH} / \mathrm{LL}$ 9/30/96 (System replacement) 
26) FACILITY: Federal Building, East ADP Room Vault

Halon

Content: Main $-141^{\#}$

Basis: Property protection of computer facility.

Facility has long-term mission.

Phase-out: For the short term, because this facility is

continuouslystaffed, it is being reconfigured for manual

release. After an evaluation has been conducted to determine an appropriate alternative means of suppression, the system will be deactivated and replaced.

Target

Date:

9/30/94 (Evaluatión planned for completion)

Actionee: ICF KH/LL

27) FACILITY: Federal Building, Room G-51 Communications Center

Halon

Content: Main $-282^{\#}$

Basis: Property protection of computer facility.

Facility has long-term mission.

Phase-out: For the short term, the system will be maintained in an automatic suppression mode activated by cross-zoned smoke detectors. After an evaluation is conducted to determine an

Target appropriate alternative means of suppression, the system

Date: will be deactivated and replaced.

Actionee: ICF $\mathrm{KH} / \mathrm{LL}$

$3 / 31 / 95$ (Evaluation planned for completion)

9/30/96 (System replacement) 
DOE/RL-94-86

This page intentionally left blank. 
DOE/RL-94-86

\section{APPENDIX IV}

CERTIFIED RECYCLING AND RECLAMATION EQUIPMENT 


\section{DOE/RL-94-86}

This page intentionally left blank. 
Table IV-1. Certified Recycling and Reclamation Equipment. (2 sheets)

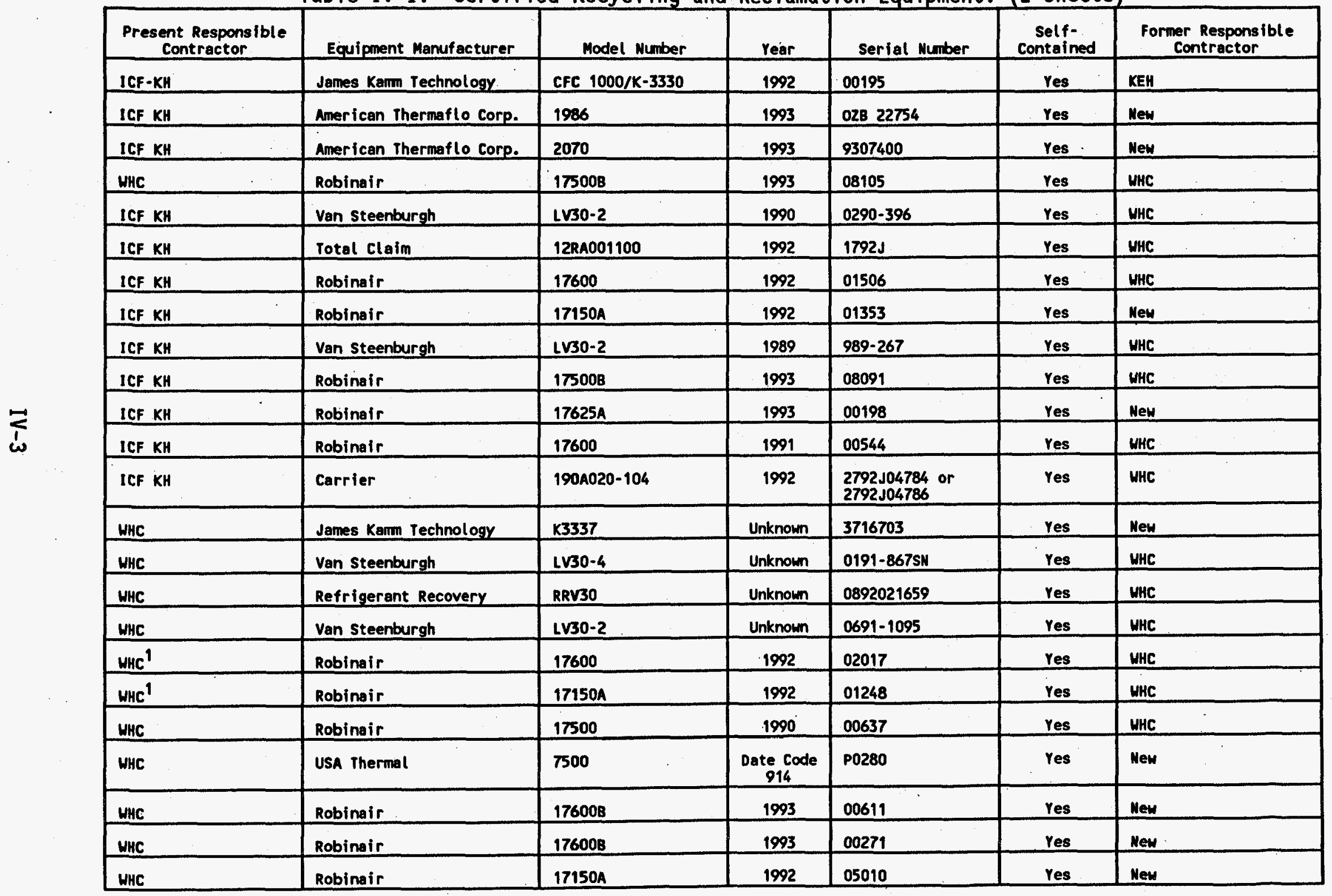


Table IV-1. Certified Recycling and Reclamation Equipment. (2 sheets)

\begin{tabular}{|l|l|l|l|l|l|l|}
\hline $\begin{array}{c}\text { Present Responsible } \\
\text { Contractor }\end{array}$ & \multicolumn{1}{|c|}{ Equipment Manufacturer } & Model Number & rear & \multicolumn{1}{c|}{ Serial Humber } & $\begin{array}{c}\text { Self- } \\
\text { Contained }\end{array}$ & $\begin{array}{c}\text { Former Responsible } \\
\text { Contractor }\end{array}$ \\
\hline UHC & James Kamm & K3336 & 1992 & 1930388 & res & Mew \\
\hline
\end{tabular}

1 Equipment will be transferred from UHC to Bechtel Manford Inc. on July 1, 1994.

ICF KH = ICF Kaiser Hanford

UHC = Westinghouse Hanford Company 


\section{MVAC RECOVER/RECYCLE OR RECOVER EQUIPMENT CERTIFICATION FORM}

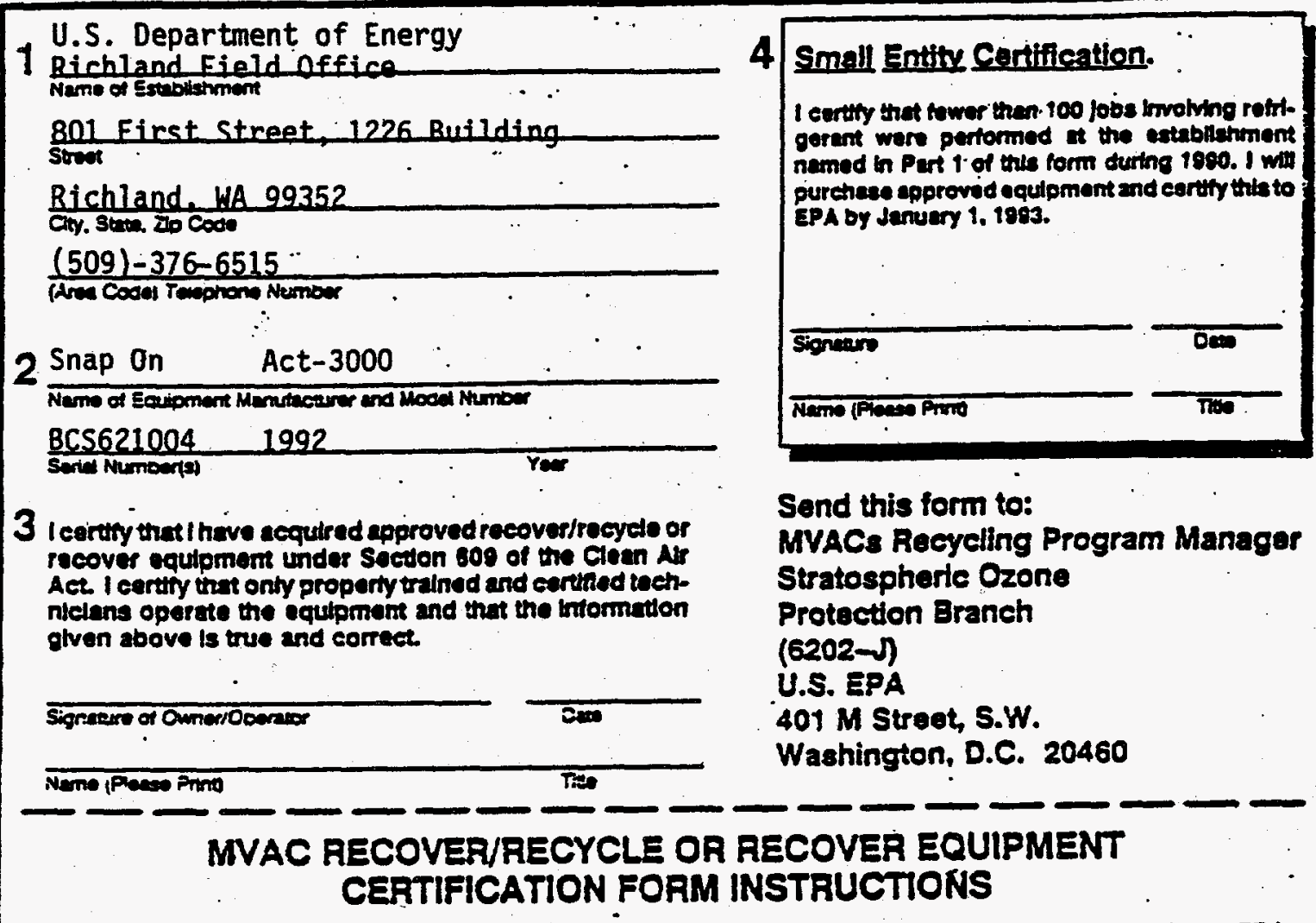

Motor vehlete racover/recy do or recover equtpment must be sequtred by Jemuary 1,1992 and cartiled to EPA on or before January 1, 1993 under Secton 609 of the Clean. Air Ace To cartity your equipmem, piease com. plote the above form according to the following Instruedons and mail to EPA af the following addrease MVACB Aecjeling Program Managor, Stratospherte Ozono Proteedon Branch, (6202-J), U.S. EPA, 401 M Strost S.W., Wastington, D.C. 20460.

1 Please provide the name, address and ielephone number of the exablisnment whors the recoverinocyele or recover equipment is locaved.

2 Please provide ne name brand, model mumber, year, and serfal mumberfst of the recovertrocycte or rocover equipment acquined for wee at ine above esteblishment

3 The certication staremen must be signed by the persen who hes acquined the recovertrecyele or recover -quipment pere person may be une owner of the espalishment or another responsible offlcen. The person who signs is certitying urex they have acquired the equipment, that exen inotvidual authorized to use the equipment is proporty trained and certined, and orat ons intermaton providod is tre and correct.

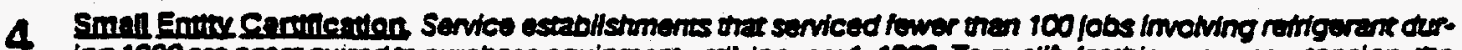

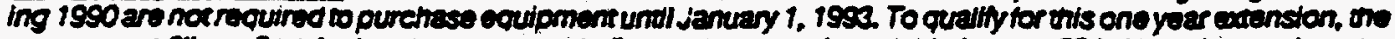
owmer meax fill our Part 1, sign the scatement in Part 4 above, and send this tom to EPA. Upon inspecton, uns

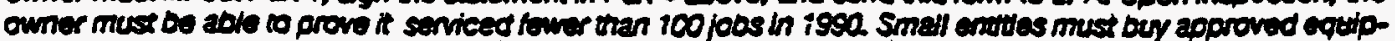
ment and centify to EPA by Janiver $i$, t993.

325041-3

Appendix 3 to Subpart B-standad for

Recover Equipuent [Recervod]

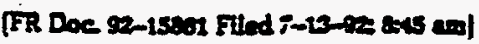

mume coor anom 


\section{MVAC RECOVER/RECYCLE OR RECOVER EQUIPMENT CERTIFICATION FORM}

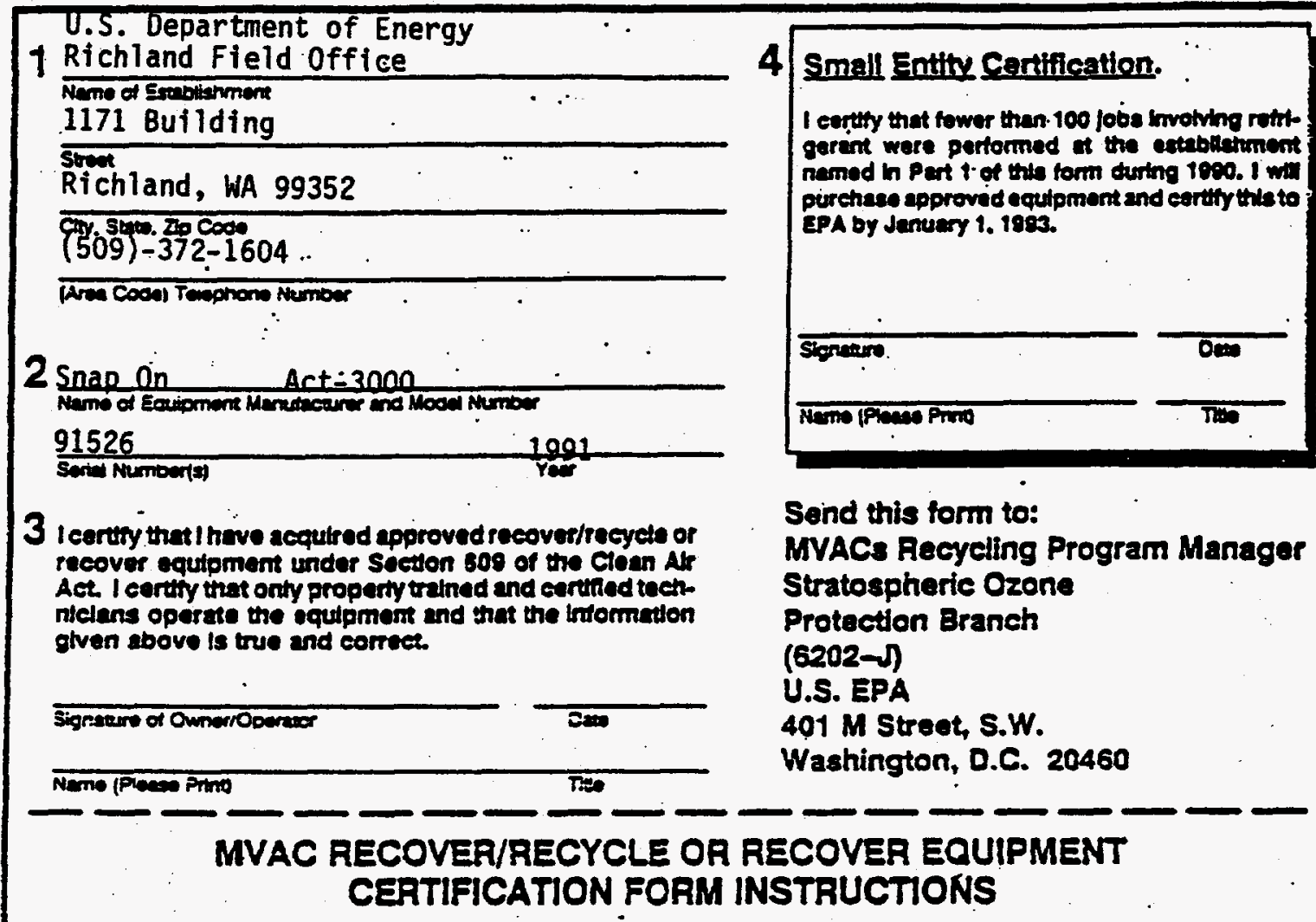

Motor vehicle recoverifecy de or recover squipmom mut be sequtred by Jenuary 1,1902 and certined to EPA on or before January 1, 1993 under Secton 609 of the Clean. Atr Act. To certhy your equipment pleses eomplete the above form aceorting to the following insurestons and mall to EPA at tho following addrease MVACs Rocyellng Program Marager, Stratosphorte Ozone Protecton Branch, (6202-V), U.S. EPA, 401 M Streat, S.W., Washington , D.C. 20460.

1 Please provice the name, address and ialephone number of the esrablishmem whers the recovertrecrele of recover equipment is locatod.

2 Please provide the name bend, model mumber, year, and sental number(st of the recoventrecyede or recover equipment acquired tor use at the above ssablismment

3 The cerdfication stemement must be signed by the persen who hes acquired the recovertrecyete or rocover equipment phe person moy be the owner of the escallishment or another rosponsible ofilcen). The person who

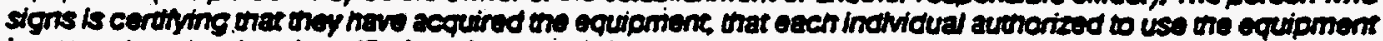
is propenty trained and certifed, and thet the intomaton provided is oue and correce

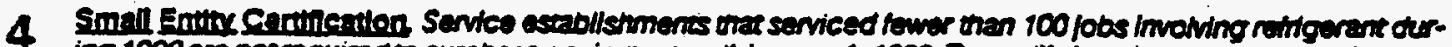
ing 1990 are not required to purchase equipmenumbl vantery 1, 1993. To qualfy for this one yoar eutenston, ons

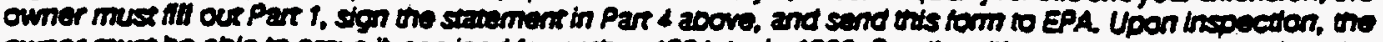

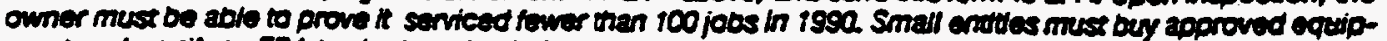
ment and corrity to EPA oy Jenivary $1,1993$.

sesess-3

Appoodix 3 to Subpert B-Standaxd for

Reover Equipuent [Reacrved]

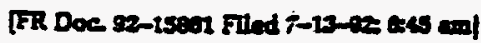

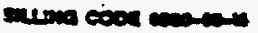


MVAC RECOVER/RECYCLE OR RECOVER EQUIPMENT CERTIFICATION FORM

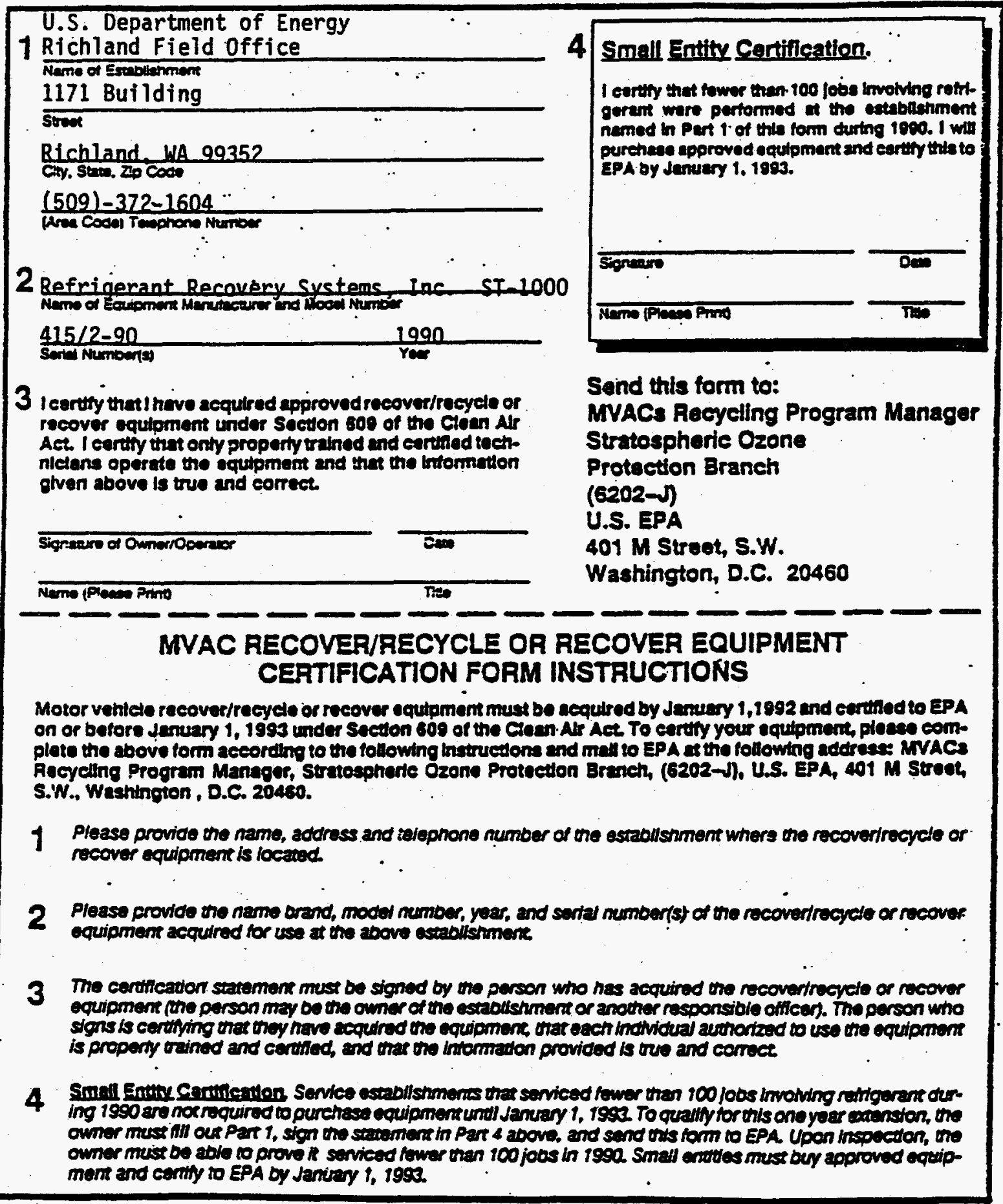

\section{s2soss-1}

Appeadix 5 to Solopert B-Standend for

Recover Equiponent [Rewnd]

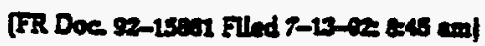

mene coos 
MVAC RECOVER/RECYCLE OR RECOVER EQUIPMENT CERTIFICATION FORM

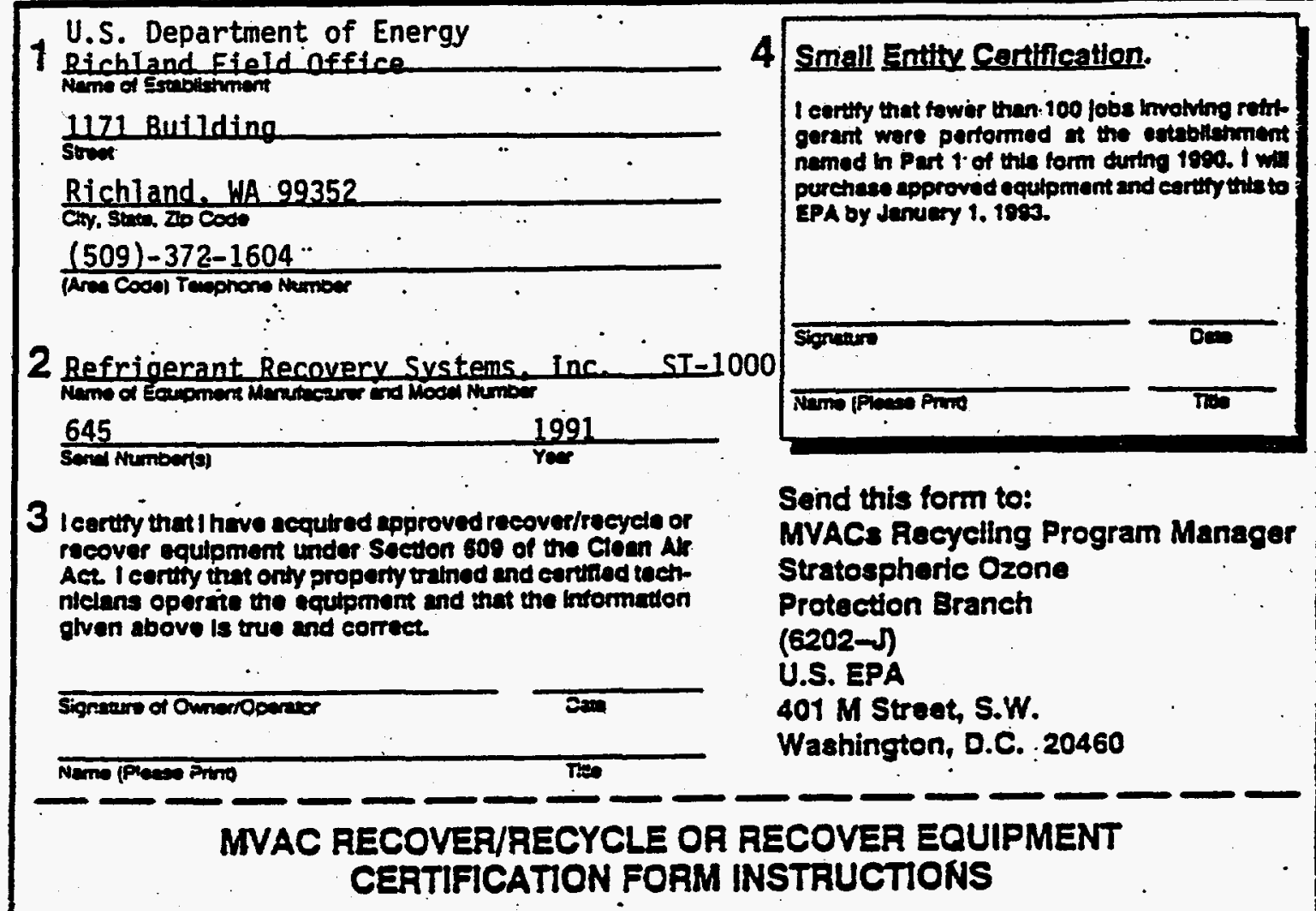

Motor vehlete recove/recyele or recover equtpment muat be sequtred by Jenuary 1,1982 and certined to EPA on or before Jemuary 1, 1993 under Secton 609 of the Clean. Al Act. To certity your equipmemt pleane com. ptets the above form aceording to the folowng hstruesons and mall to EPA a the followng addrese: MVACs Aocjeling Program Manager, Struospharte Ozene Protection Branch, (6202-J), U.S. EPA, 401 M Stropt, S.W.. Washtington, D.C. 20460.

1 Please provice the name, address and ielephone number of the estallshment where the recovertrecycte or recover equipment is locaud.

2 Please provide the name brand, moded number, year, and serlal number(st of the recovertrecycle or rocover equipment acquired tor use at tho above esrablisment.

3 The centifcadon sememen must be signed by the persen who has acquined the recovertrocyete or recover

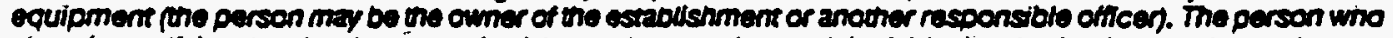
signs is certifing that they heve ecquired the squjpment, that each individual authorizod to cse the equipmom is property oraned and cortifed, and that the intematon provided is vue and comect

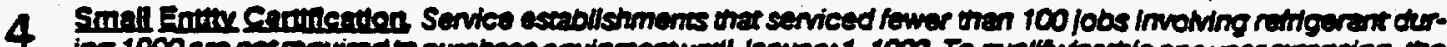

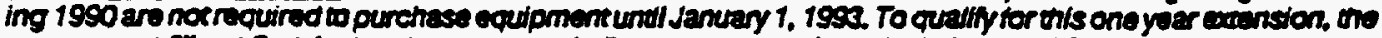
owner mess fill our Pat 1. sign the statement in Part 4 above, and send bis form to EPA. Upon inspocton, tho

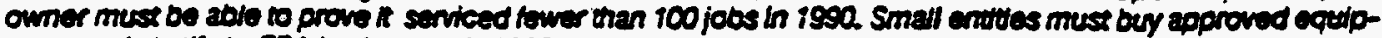
memt and cermy to EPA by Janiery 1, 1993.

32sess-3

Appenditx 5 to Sebpext B-Stondind for

Recover Equipionent [Rewived]

(FR Dec P2-15eor Filad 7-20-0as and

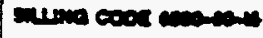




\section{MVAC RECOVER/RECYCLE OR RECOVER EQUIPMENT CERTIFICATION FORM}

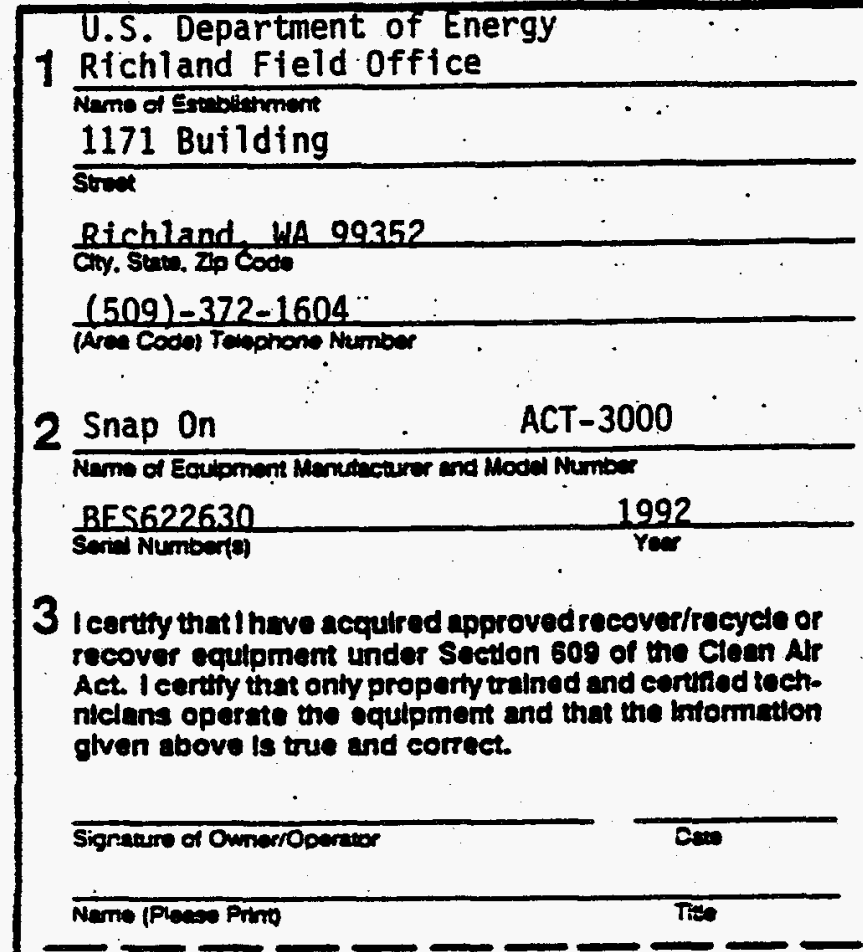

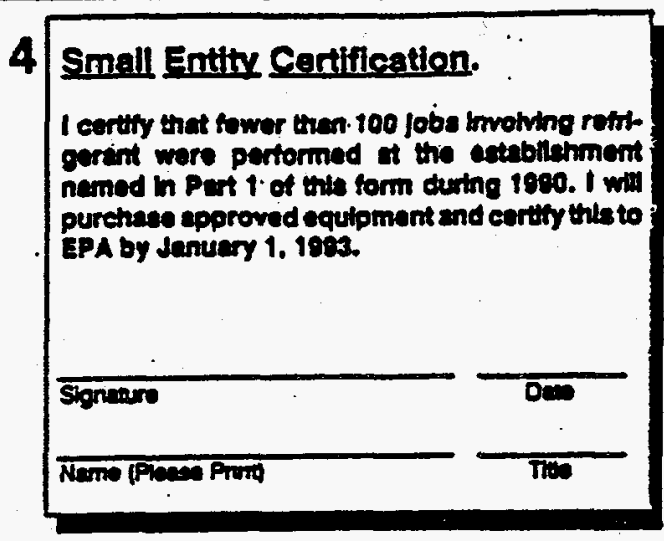

Sond this form to:

MVACs Recycling Program Manager Stratospherie Ozone

Protection Eranch

$(6202-\sqrt{)})$

U.S. EPA

401 M Street, S.W.

Washington, D.C. 20460

\section{MVAC RECOVER/RECYCLE OR RECOVER EQUIPMENT} CERTIFICATION FORM INSTRUCTIONS

Motor venlete recover/recycle or recovar equfpmom must be acquired by Jenuary 1,1992 and certhed to EPA on of bofors January 1, 1993 undor Sueton 609 of the Cleen. Al Act. To certty your equipmant, plesse complete the above form accoreting to tho following instruestons and mall to EPA at the following address: MVAC: Recyeling Program Manager, Stratosphorte Ozone Protoetton Branch, (6202-J), U.S. EPA, 401 M Streot, S.W., Wastington, D.C. 20460.

1 Please provide the name, address and telephone number of the establishment whers the recovertrecycte or recover equipment is located.

2 Please provide the name brand, model mumber, year, and sertal mumber(st of the recoverirecyete or recover equipment acquired tor use at the above extablishment.

3 The certificadion scarement must bo signed by the persen who has acquired the recovertrecycle or rocover equipmem (the persson may be the owner of the escabissment or another responsibte officen. The porson who signs is certifying thet they have acqutrod the equipment that each inowidual authorized to use the equipment is property trained and cerdfied, and that the intomadon provided is tres and corroce.

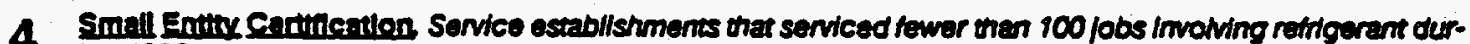
ing 1990 are not required to purchase equipmemt untl January 1,1993 . To qually for this one year extension, the owner must fill out Part 1, sign the statement in Part 4 above, and send tits form to EPA. Upon Inspecton, the owner must be ablo to prove it serviced fower than 100 jous in i990. Small entules must ouy approved equipment and centiy to EPA by Janiary 1, 1993.

s2sess-1

Appondix 3 to Subpart B-standard for

Rocover Equipment [Recurved]

[FR Doc se-15801 Filid 7-13-92 8es am]

muma coor wasen 


\section{MVAC RECOVER/RECYCLE OR RECOVER EQUIPMENT CERTIFICATION FORM}

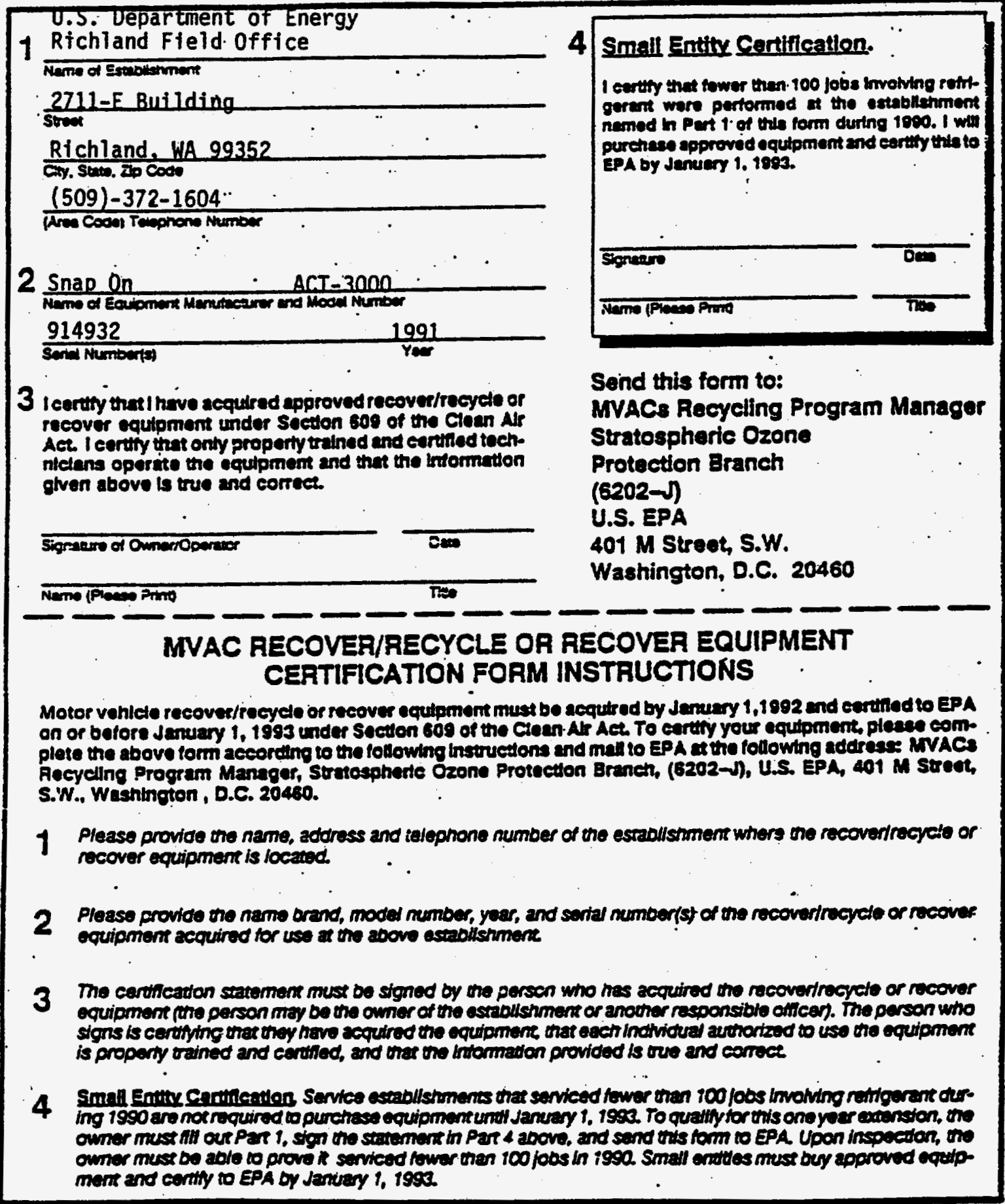

325095-3

Appondtix 9 to Sabpert B-Stondard for

Recove Equiponent [Renerved]

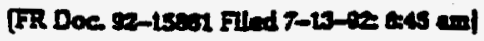

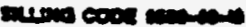


DOE/RL-94-86

DISTRIBUTION

Number of copies

ONSITE

19

U.S. Department of Energy,

Richland Operations office

D. H. Alexander

S7-51

G. M. Bell

A5-52

J. J. Broderick

A7 -27

R. A. Liias

A5-20

A. E. Teimouri

A5-15

R. P. Carter

S7-55

R. M. Carosino

A4-52

C. E. Clark

B. E. Hill

A5-15

M. B. Hitt

R3-81

R. A. Holten

P. W. Kruger

A7-27

J. Mecca

R3-81

K8-50

H. P. Mooers

R3-81

P. E. Rasmussen

A5-55

S. D. Stites

A7 -80

R. L. Stewart

A5- 15

A5-19

W. A. White

J. W. Wiley

G3-18

A6-54

25

Bechtel Hanford. Inc.

D. R. Baker

T. F. Demmitt

$\mathrm{X} 0-71$

J. H. Dunkirk

H4-79

R. L. Donahoe

H4-80

S. L. Feaster

H4-79

R. J. Gimera

H4-79

M. J. Hughes

X5-54

J. James

H6-03

R. J. Landon

H4-79

M. R. Morton

H4-80

L. A. Mihalic

$\times 5-55$

E. M. Mueller

H4-79

J. M. Nickels (10)

H6-05

D. D. Von der Linden

H4-80

S. R. Weil

R. H. Wyer

H4-79

H4-80

H4-80

Hanford Environmental Health Foundation

T. W. Harrison

H1-77 
DOE/RL-94-86

6

ICF Kaiser Hanford Company

$\begin{array}{ll}\text { M. J. Brown } & \text { L6-55 } \\ \text { J. D. Fulcher } & \text { S2-32 } \\ \text { S. G. Kenaston } & \text { G3-04 } \\ \text { D. M. Poor } & \text { S2-31 } \\ \text { S. L. Smith } & \text { S2-32 } \\ \text { J. A. Zilar } & \text { L6-61 }\end{array}$

4

Pacific Northwest Laboratory
E. R. Gerk
P7-63
D. D. Hatley
P7-08
H. T. Tilden
P7 -79
V. A. Young
P7-79

Westinghouse Hanford Company

R. R. Anderson

J. A. Bates

G. W. Becken

R. J. Bliss

D. J. Carrell

S. N. Cory

B. Curn

E. C. Dahl in

W. F. DeLorme

W. Dixon

R. A. Evans

E. F. Gray

E. R. Hamm

D. K. King

J. J. Luke

R. J. Meyer

J. C. Midgett

M. G. Mills

L. E. Pokos

J. A. Rivera

L. W. Vance

Central files

OSTI (2) $\times 3-76$

H6-22

S3-30

R3-50

H6-22

H6-20

H6-25

G1-20

X8-25

H6-21

HO-31

R3-50

S4-64

B3-15

H6-25

G1 -56

N2-51

G1-10

S4-64

B2-16

H4-16

L8-04

L8-04 